\title{
Digital Busine
What's Next?
}

Hendro Wicaksono

President Comissioner PT Labdha Teknika Nusantara

Professor of Industrial Engineering, Jacobs University Bremen

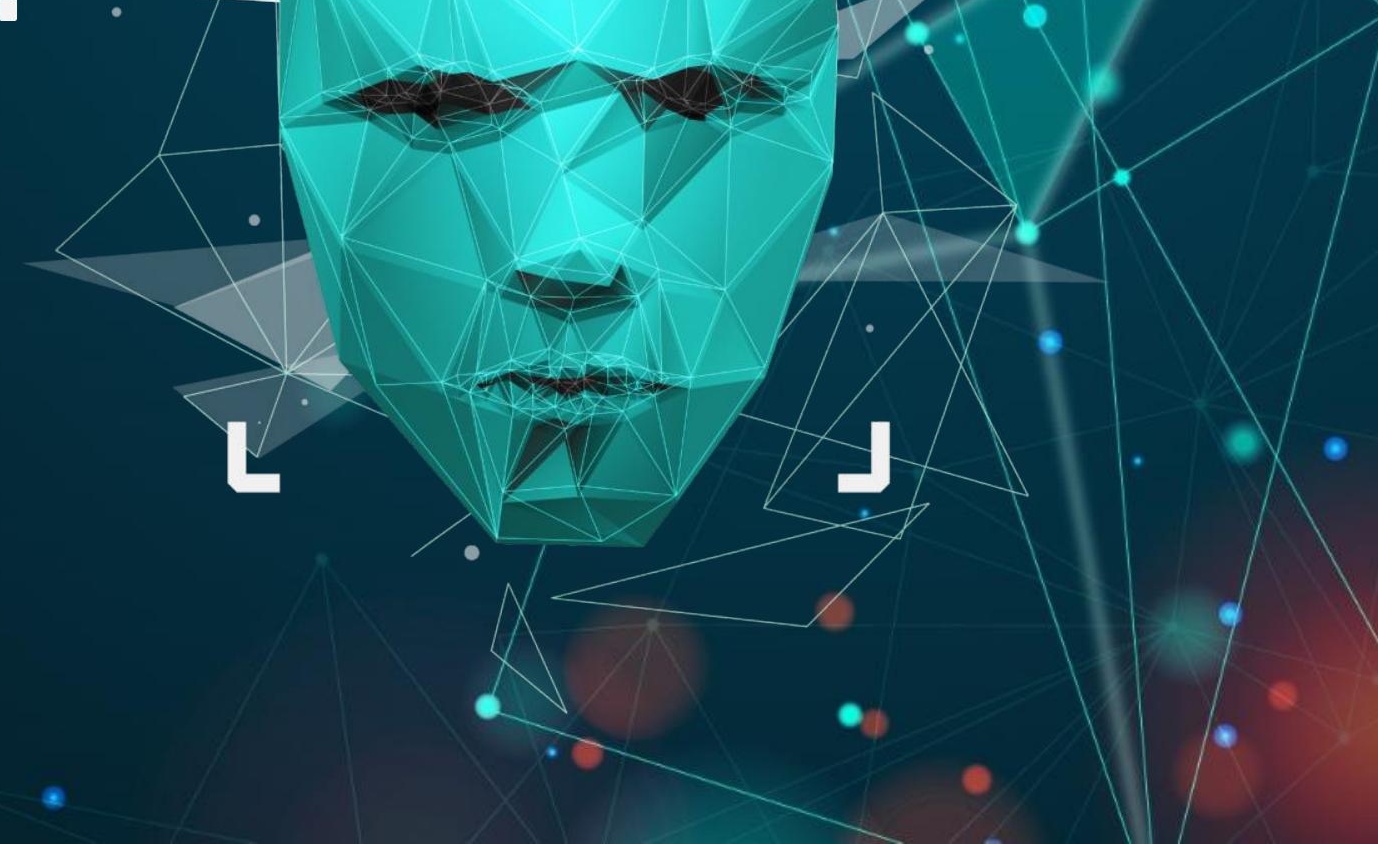




\section{OUTLINE}

\section{Indústrial
$01\left\{\begin{array}{l}\text { revolutions and } \\ \text { their } \\ \text { technological }\end{array} \quad 02\left\{\begin{array}{l}\text { Implications on } \\ \text { business and } \\ \text { society }\end{array}\right.\right.$ enablers

$03\left\{\begin{array}{l}\text { Which skills } \\ \text { should we have? }\end{array}\right.$ 


\section{Industrial revolutions}

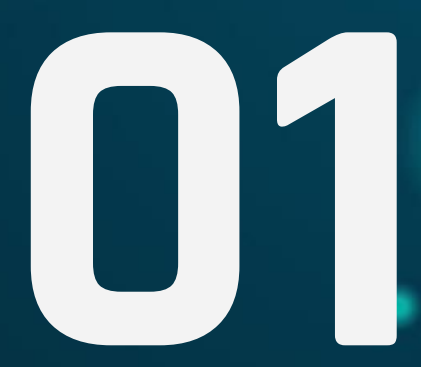




\section{What is industry $4.0 ?$}

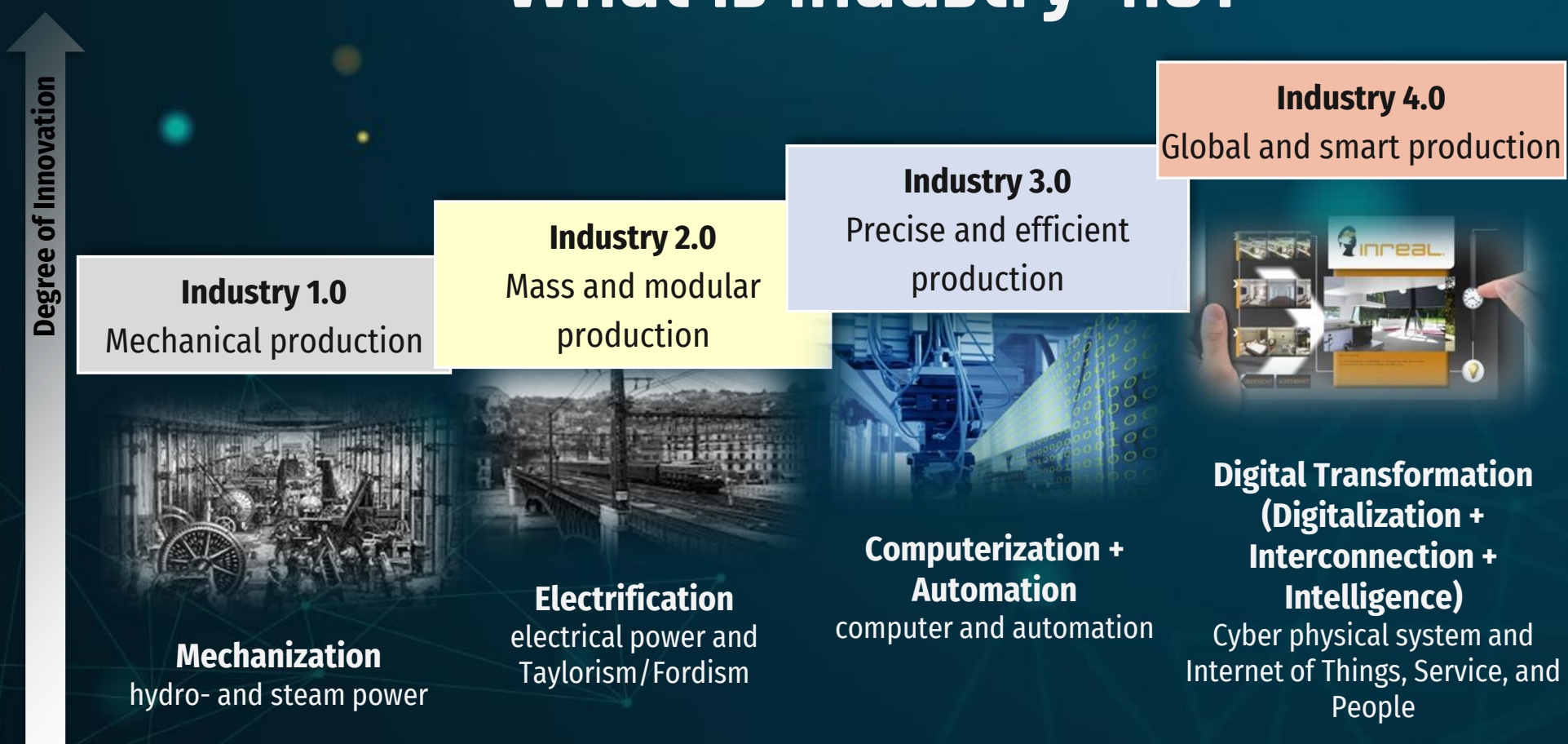




\section{Drivers}

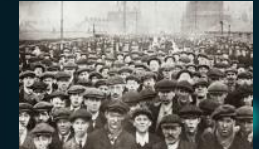

Population growth

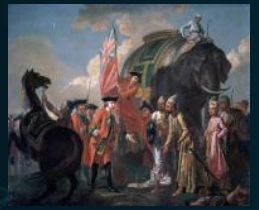

Agrarian capitalism and mercantilism are insufficient

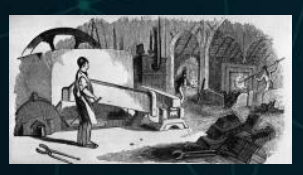

New findings in metal processing and machinery

\section{Industry 1.0}

\section{Mechanical Transformation}
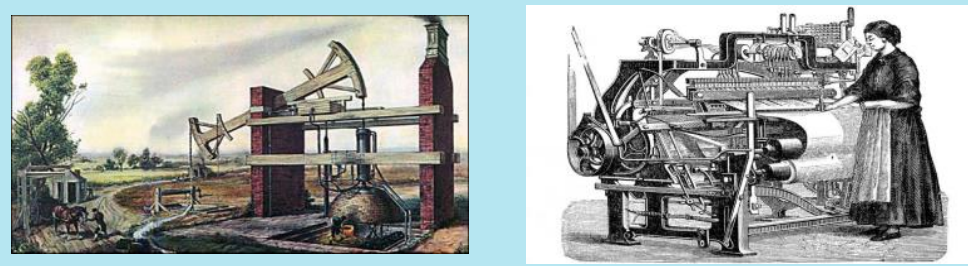

Steam-engine in mining (1712)

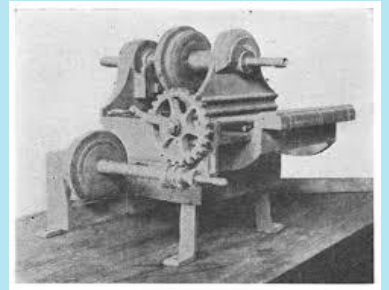

Full-metal turning lathe (1797)

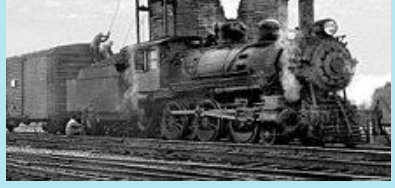

Steam locomotive (1804)

Impacts
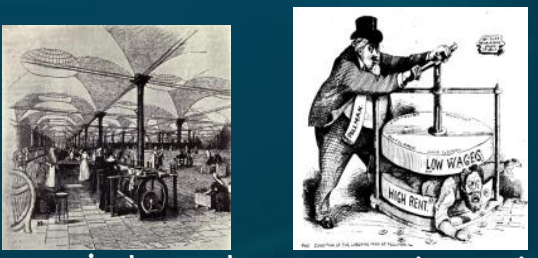

Nature independent Industrial capitalis production

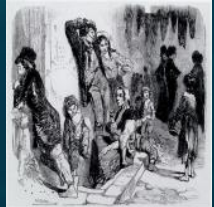

Working class, urbanization, low life expectancy

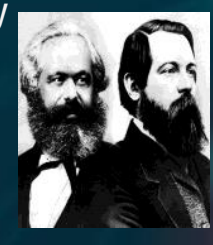

Capitalism vs. marxism

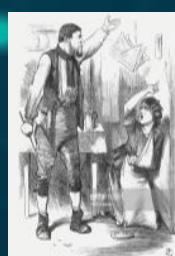

Separation of roles in a family 


\section{Industry $\mathbf{2 . 0}$}

\section{Drivers}

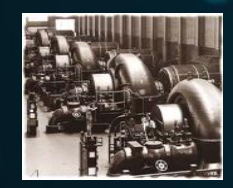

Electrical powered engines

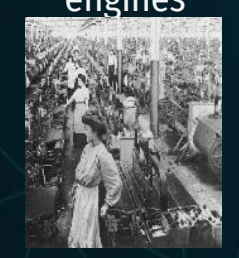

Noisy and dangerous effects of steam machines

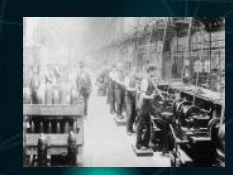

Taylorism

\section{Electrical Transformation}

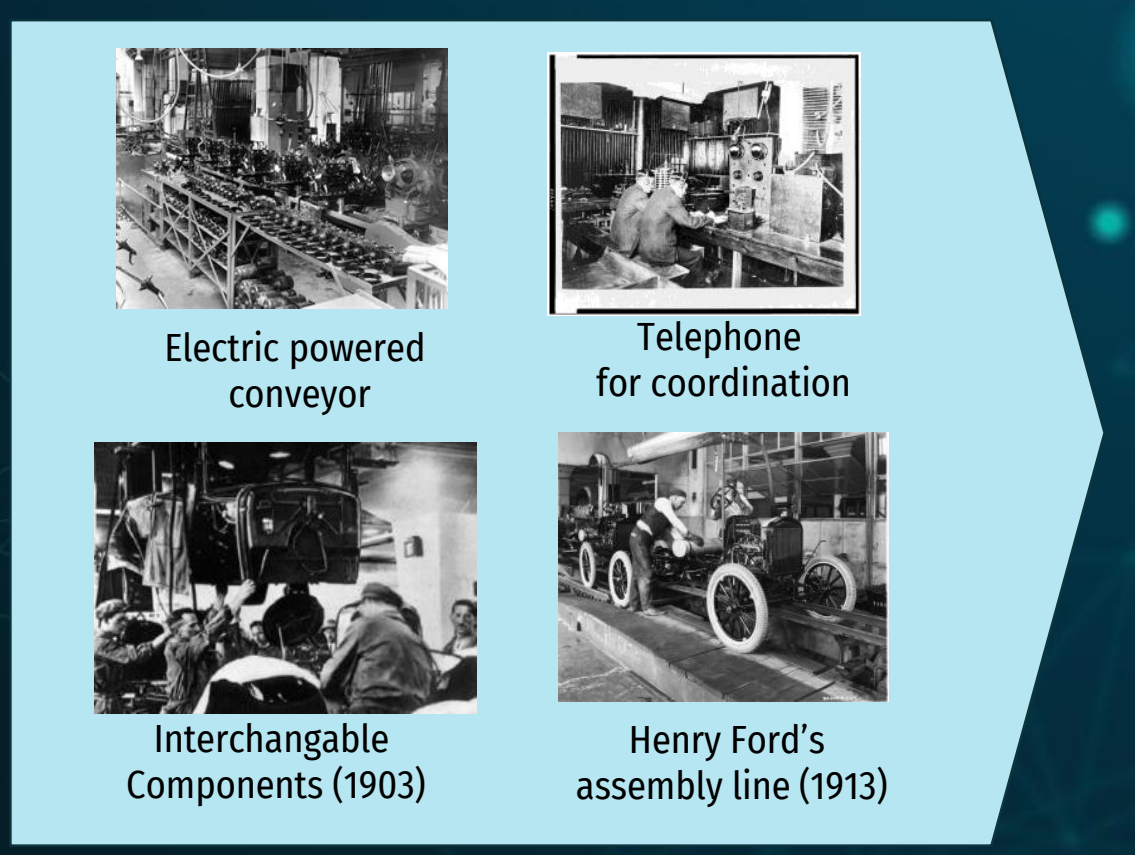

\section{Impacts}

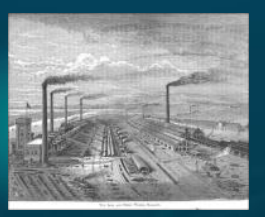

Economies of scale Growth of large

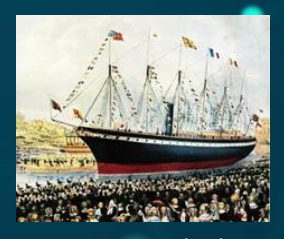

Cheap logistics enterprise

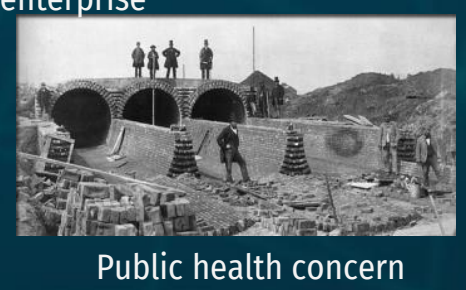

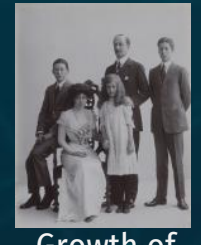

Growth of Middle class

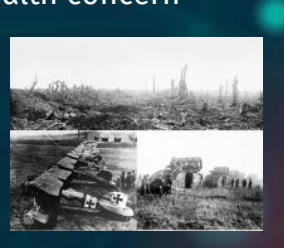

Mass weapon production and WW1 


\section{Industry $\mathbf{3 . 0}$}

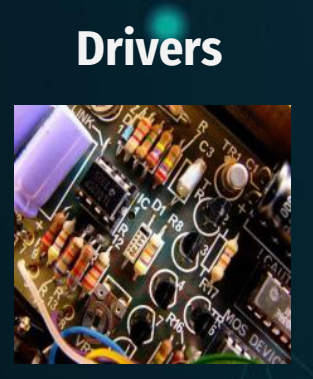

Advancements in electronics

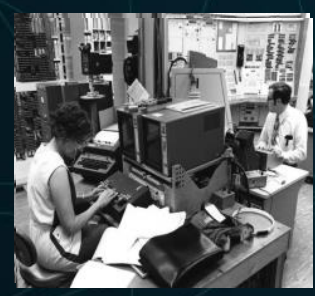

Commercial uses of computers: administration, planning, control
Computer-driven transformation

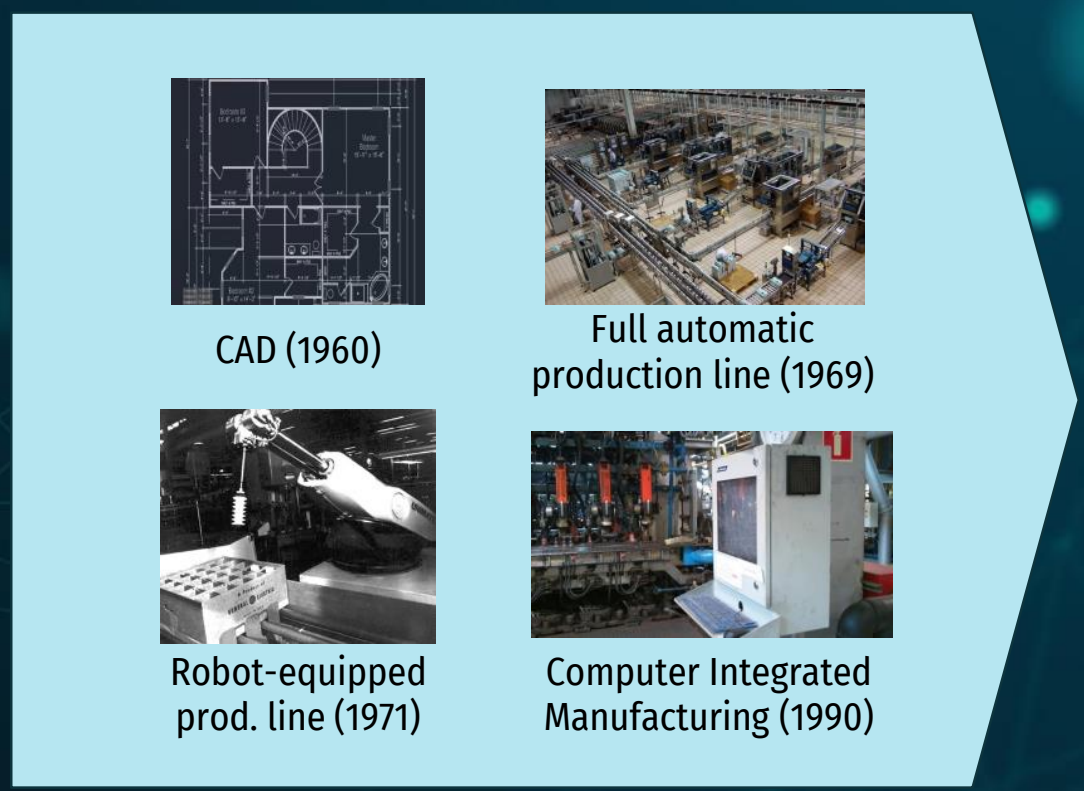

Impacts
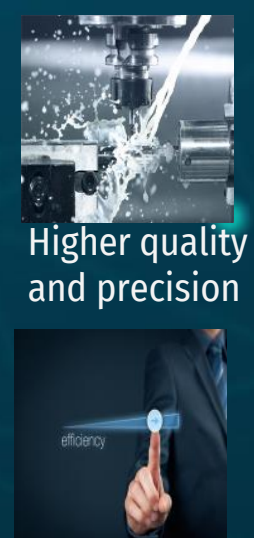

Higher efficiency through precised planning and control

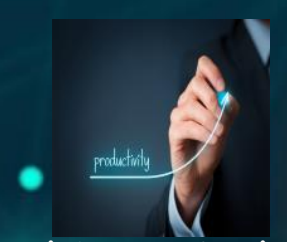

Higher productivity 


\section{Industry 4.0}

\section{Drivers}

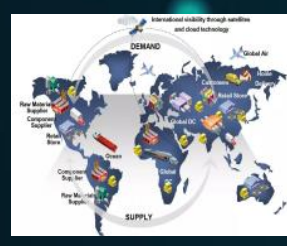

Global value chain

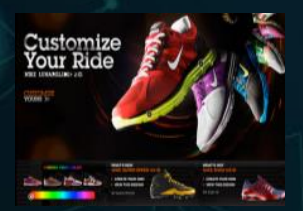

Product customization

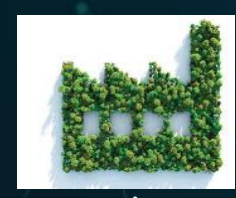

Flexible and green manufacturing

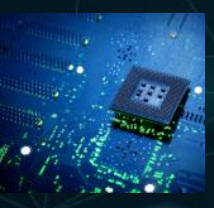

Rapid increase of computing power

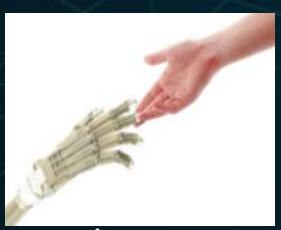

Intelligent and adaptive systems

\section{Digital transformation}

Impacts

Industry key player shifts: more opportunities for $\mathrm{SN}$ and startups

Knowledge basr distributed er

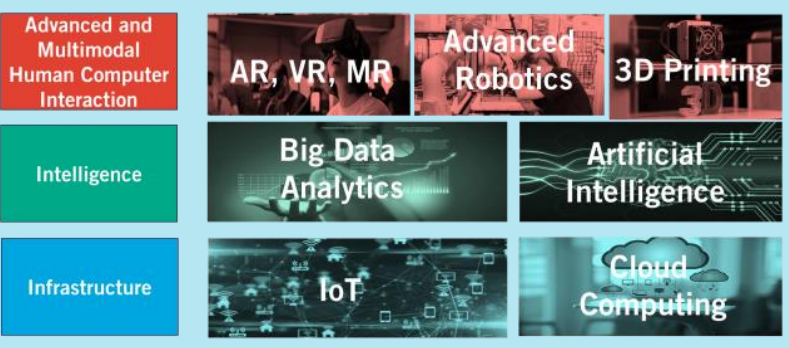

Mor

Bette

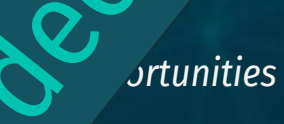

P 2 is and business chnologies Job loss, Digital m. oly loss of tax payers 


\section{The enabling technologies of industrial revolutions}
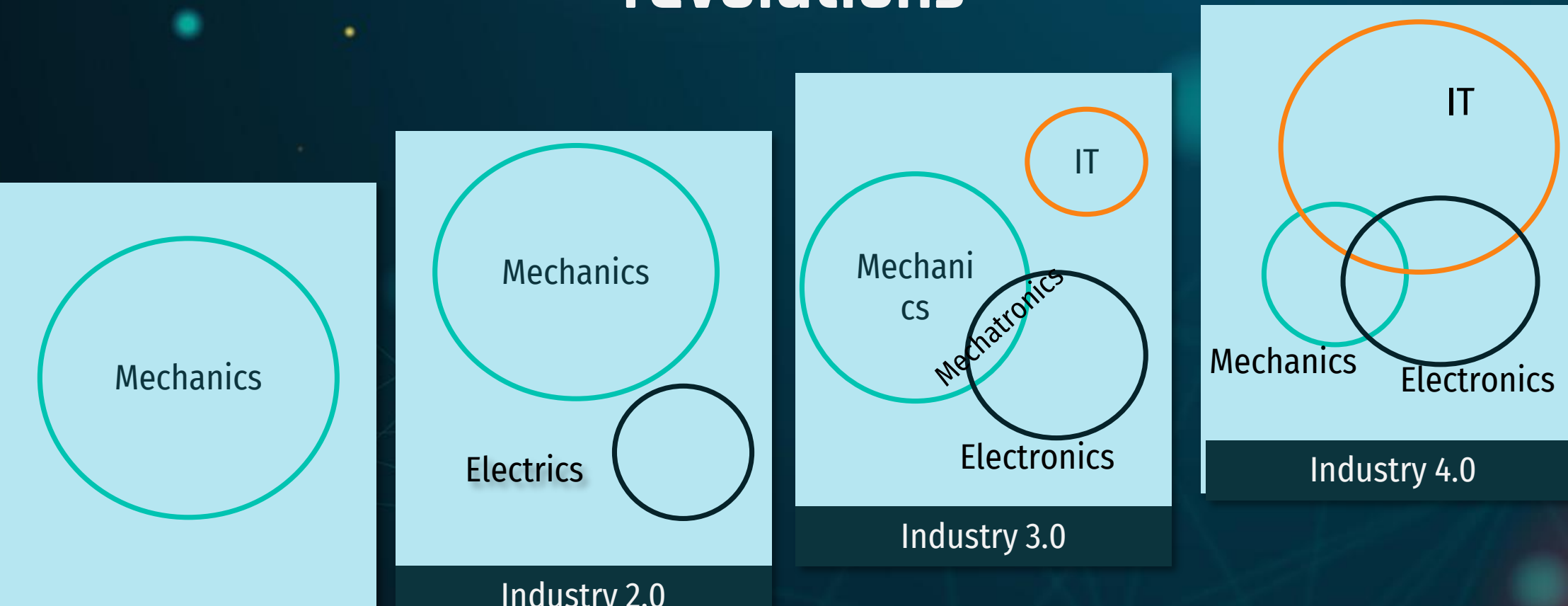

Industry 3.0 


\section{The industry 4.0 enabling technologies}

\section{Advanced and} Multimodal Interaction

Intelligence

Infrastructure and Interconnection
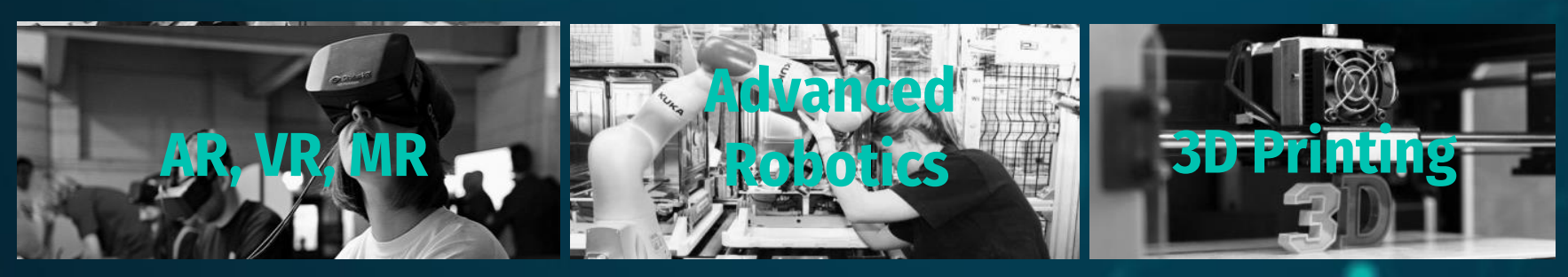

(9)

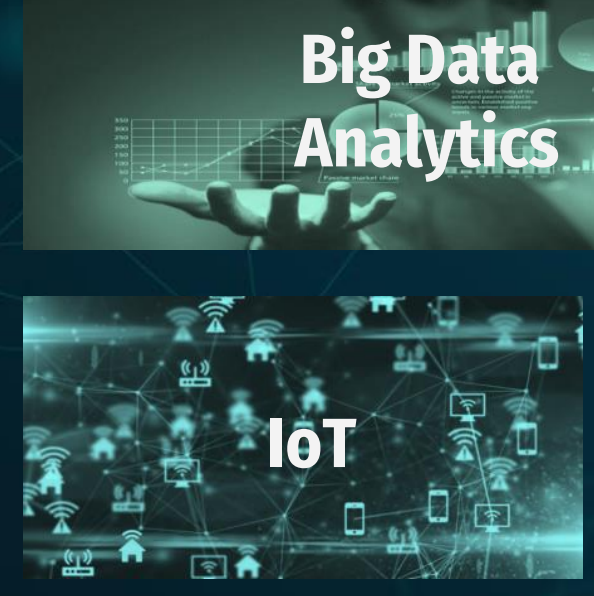

Artificia
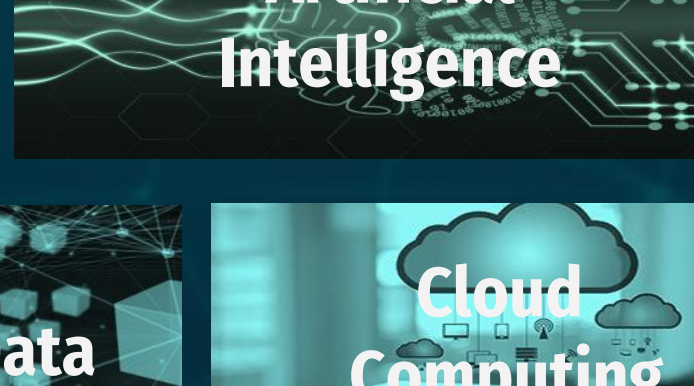

Lińccibata 


\section{What is artificial intelligence?}

The sub-field of computer science / informatics that discusses mechanisms that can mimic intelligent human behavior.

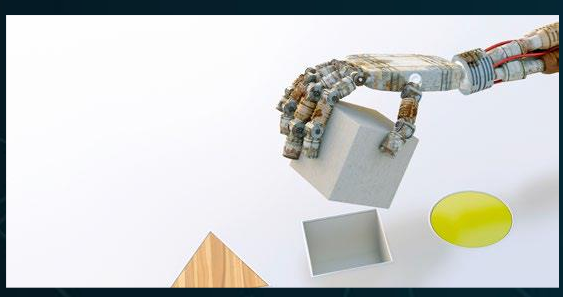

\section{Learning}

Machine learning: artificial neural network, deep learning
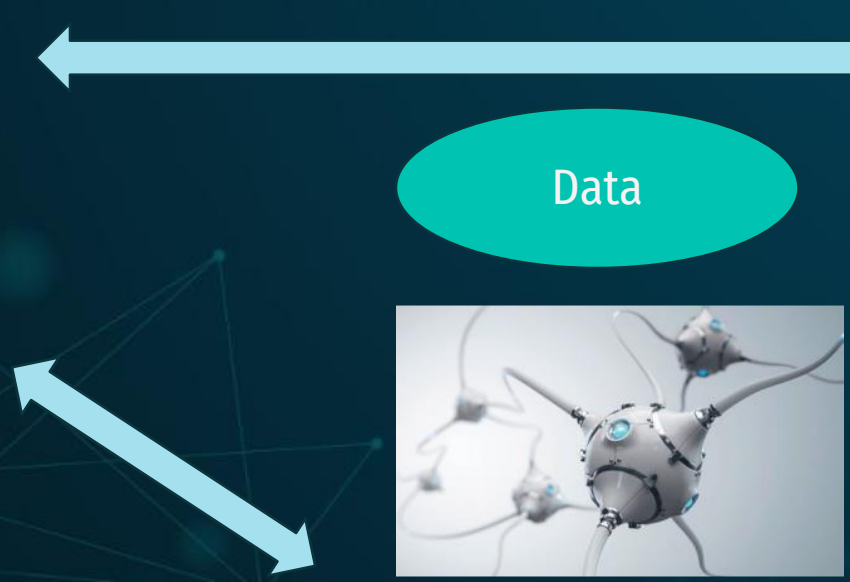

Data processing and information inferencing

Big data:

processing, searching, inferencing
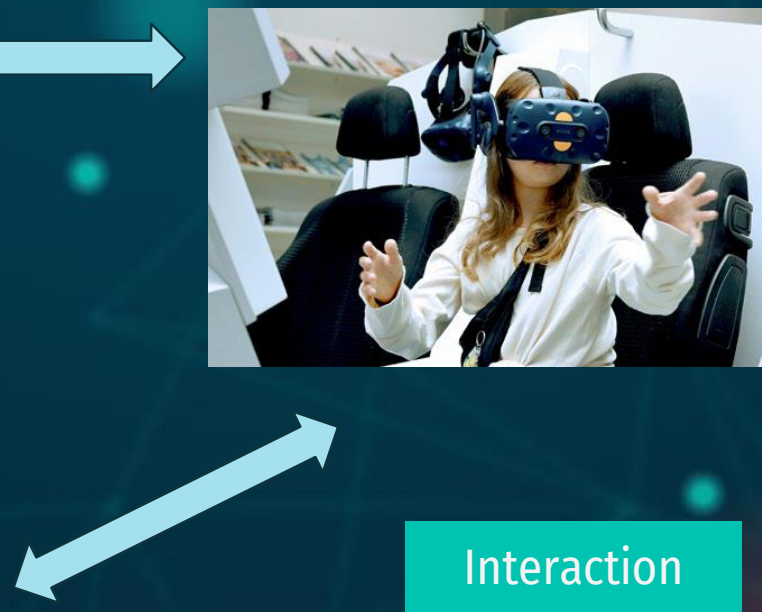

Interaction

Human-machine and machine-machine interaction $\bullet$ 


\section{Implications on business and society}

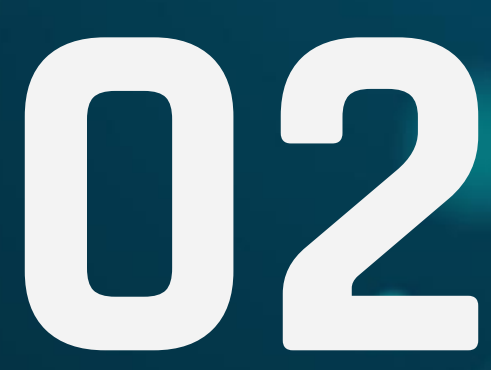




\section{The pillars of industry 4.0 end-to-end solution}

Smart Process/ Operation

Smart Product

Q

(a)

(8)

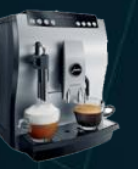

丒

(1)

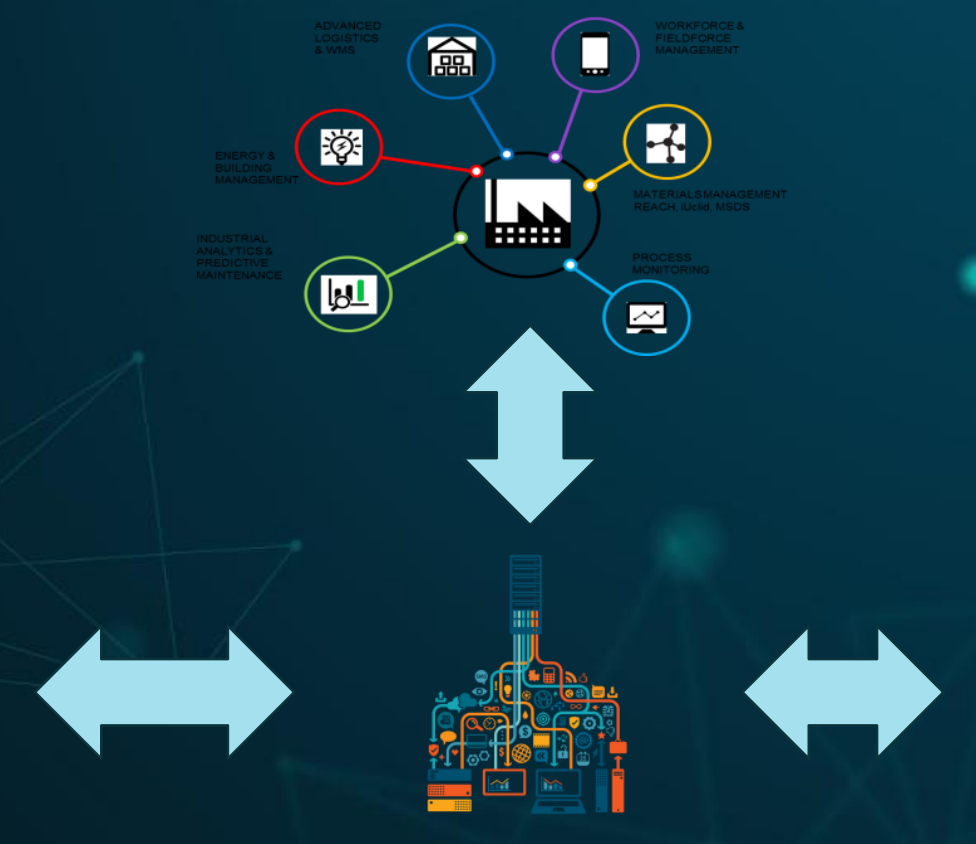

Data Driven Service
Smart Resource/ Infrastructure

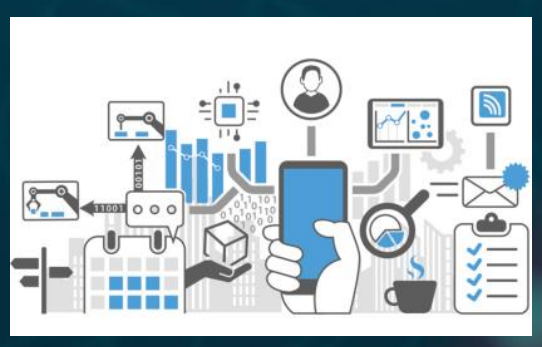

() 


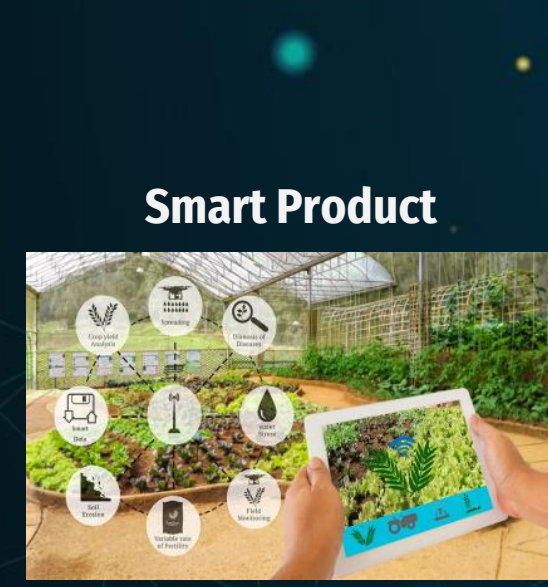

Self informing crops

\section{Smart Process/ Operation}

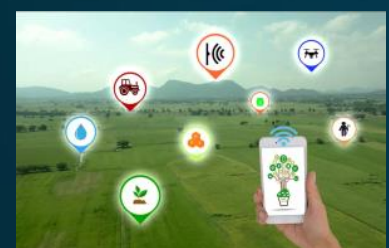

Connected farmers, suppliers, market

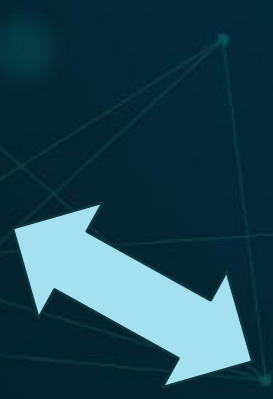

\section{Smart Resource/ Infrastructure}

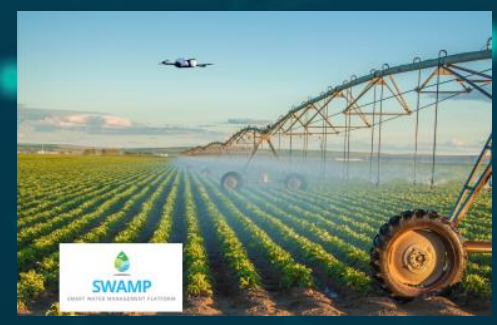

Automatic watering,

\section{Data driven service} smart transport,

smart warehouse

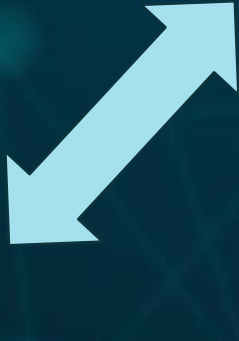


Industry 4.0 


\section{Implications on industries: data driven serviçe}
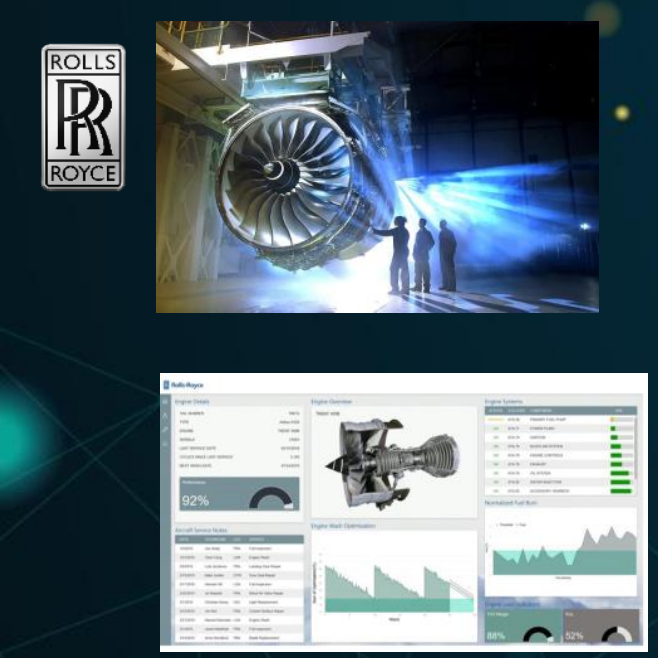

Airplane engine + real time monitoring, predictive maintenance, optimization service
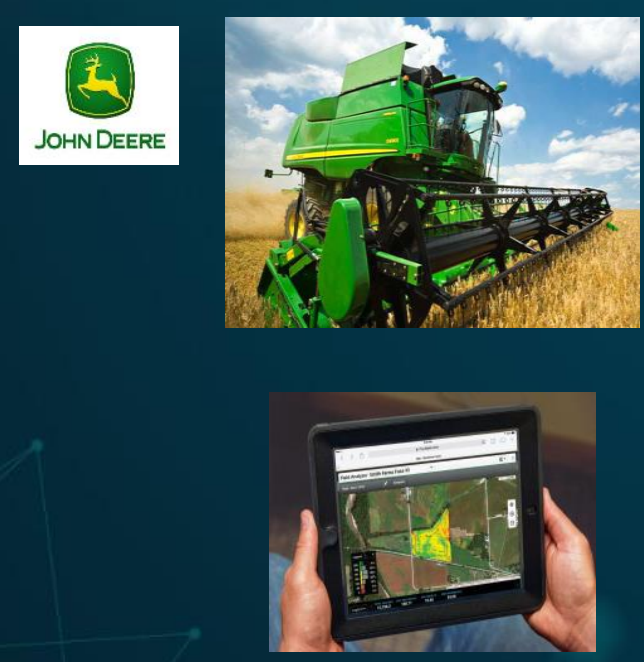

Farming machines +

Farm monitoring, social media https://myiohndeere.deere.com
RULPI LILREN
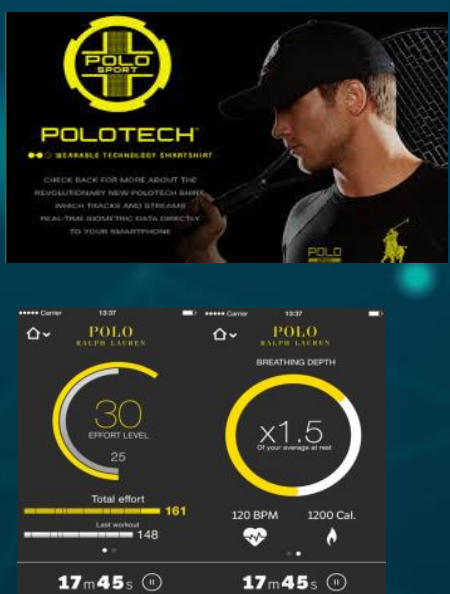

Sport shirt + Health monitoring, early warning system 


\section{Technologies changes business models}
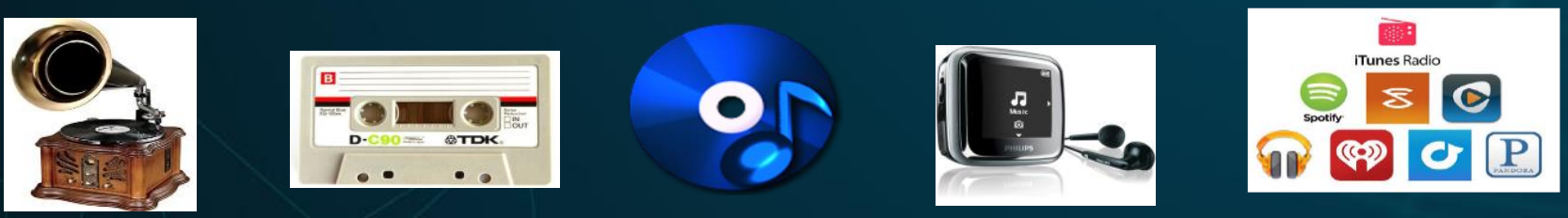

Technologies drive changes 


\section{Disruptions because of innovative business models}

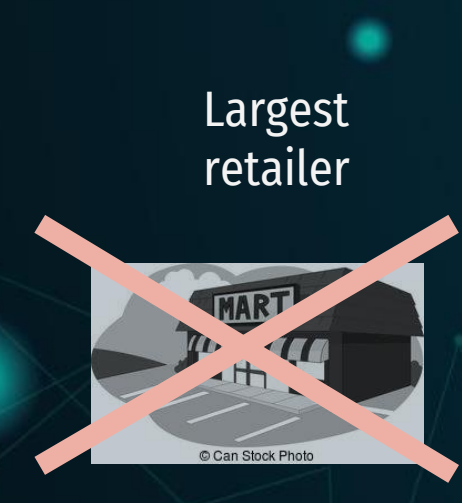

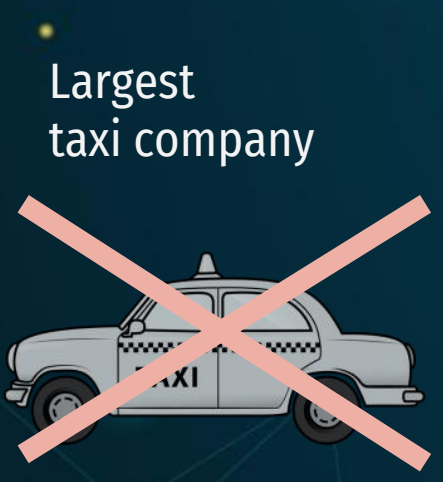

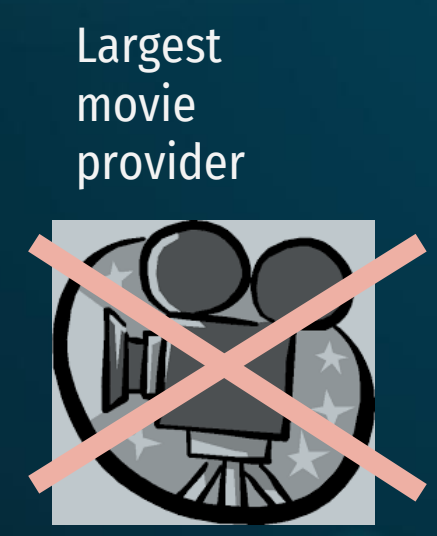

Largest

accommodation provider

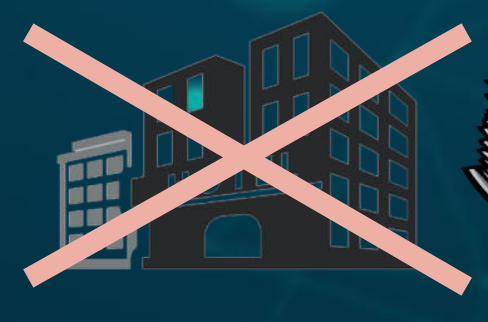

NETFLIX
Q airbnb
Largest

information

provider
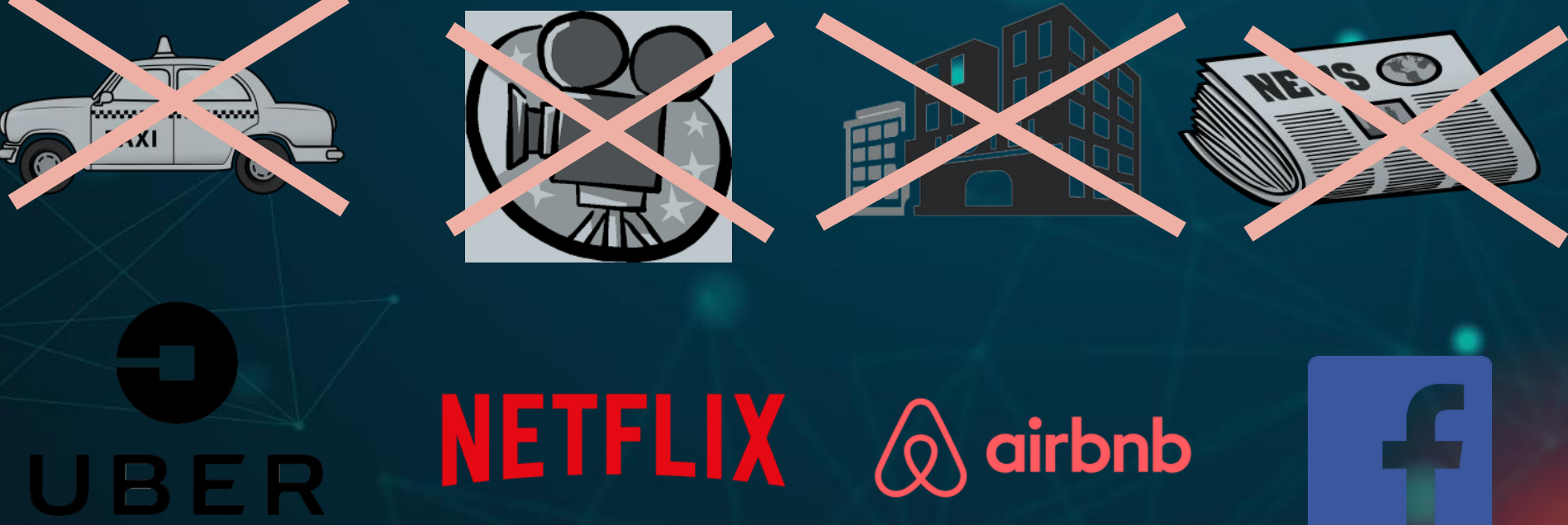


\section{Implications on jobs}

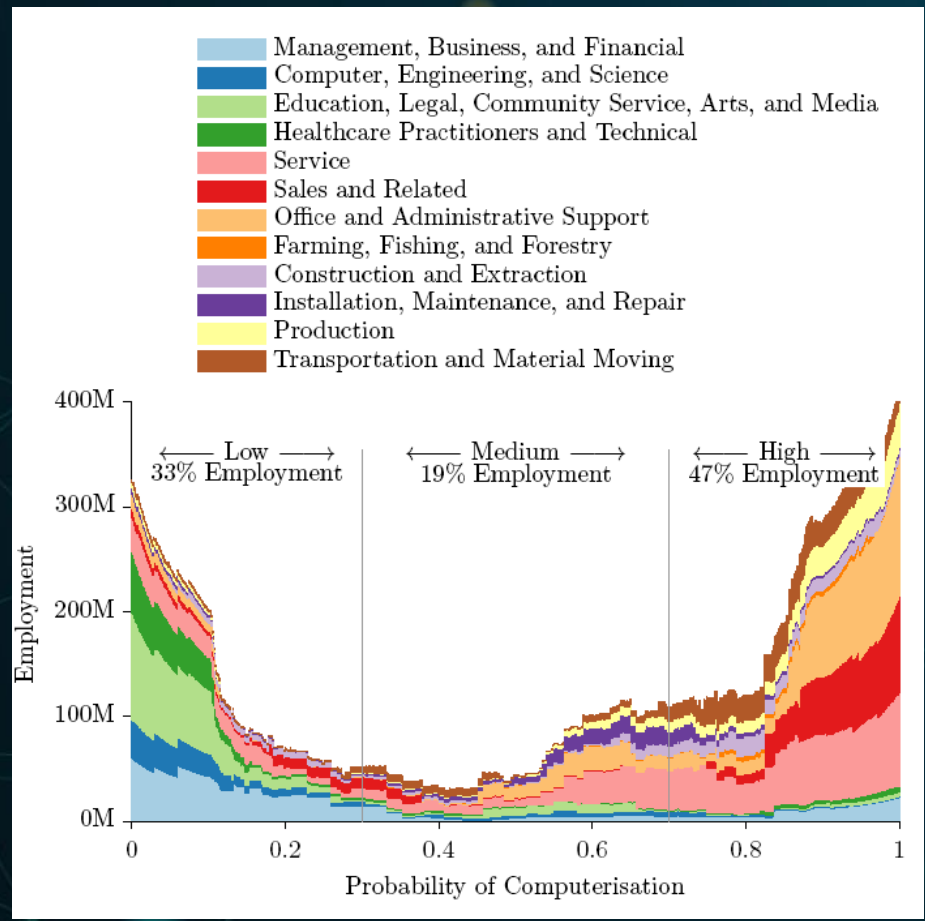

Source: Oxford University
BBCNBC HOME INTL $\checkmark$ NEWS MARKEIS INVESTING TECH MAKE IT VIDEO SHOWS MORE

SUBSCRIBE, PRO LIVE TV

Lawyers could be the next profession to be replaced by computers

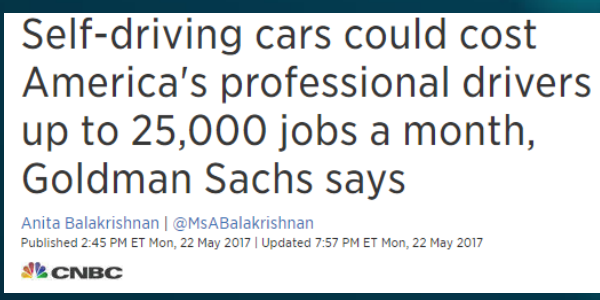

Surprisingly, These 10 Professional Jobs Are Under Threat From Big Data

- Some jobs won't exist anymore, even service based jobs

- Less amoun tof jobs and more specialized jobs

- Jobs requiring care will still survive 


\section{Jobs at high risk of automation by country.}
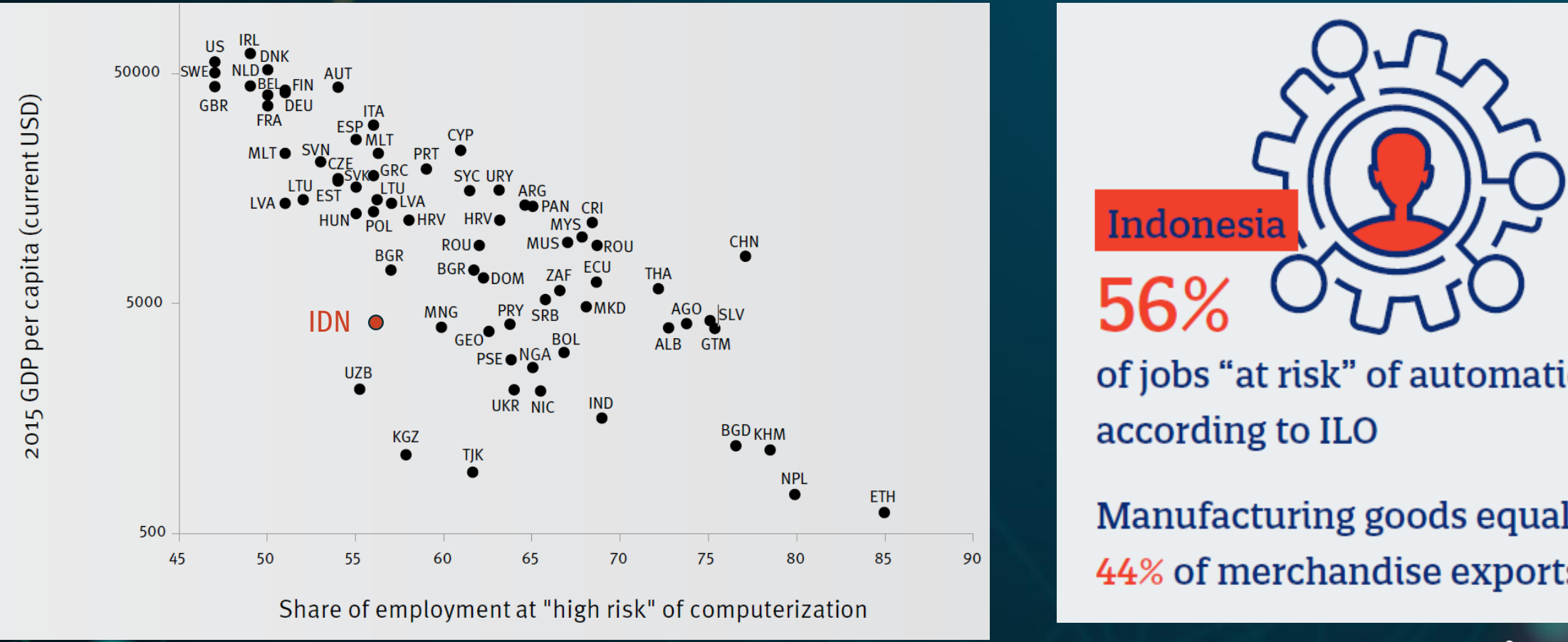

of jobs "at risk" of automation according to ILO

Manufacturing goods equal $44 \%$ of merchandise exports 


\section{Implication on entrepreneurship}

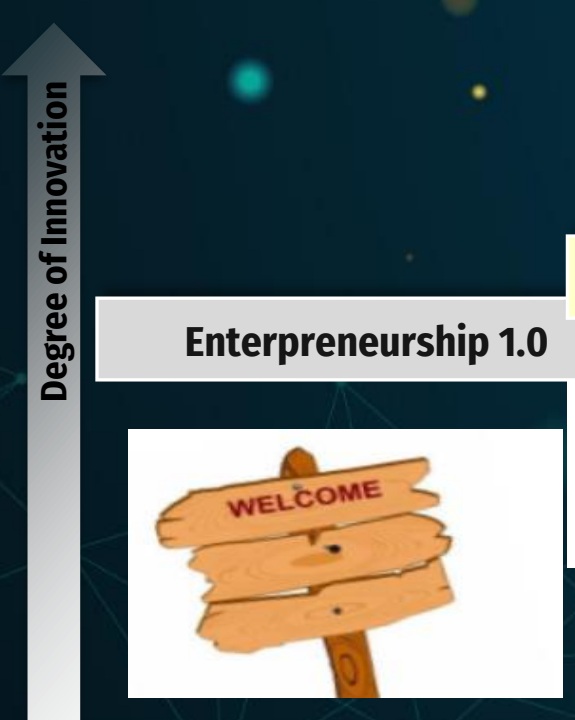

1 man show + sign

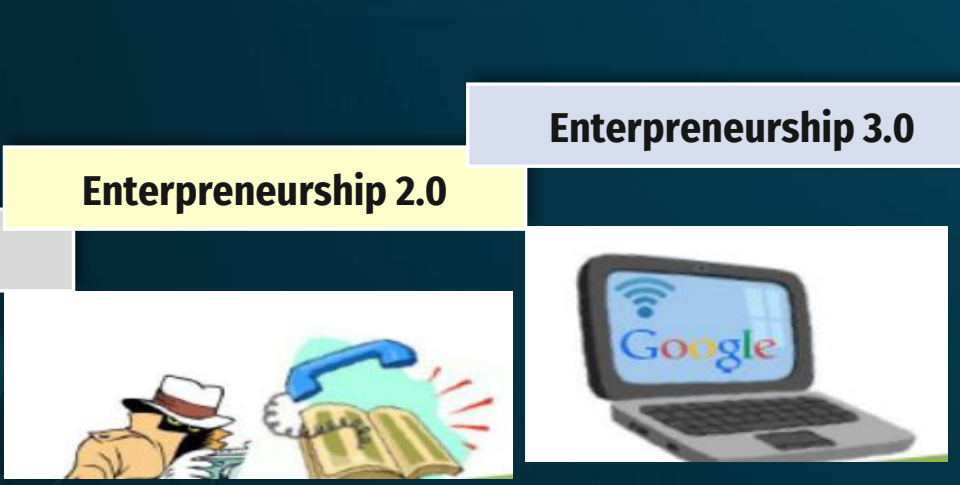

1 man show + extensive

1 man show + basic information and communication
Enterpreneurship 4.0

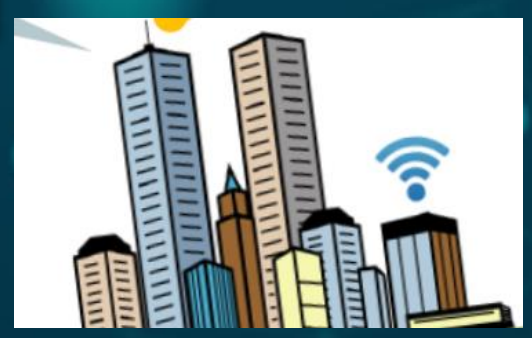

Entrepreneur's village

a village's support in information and communication communication and information 


\section{Implication on leadership}

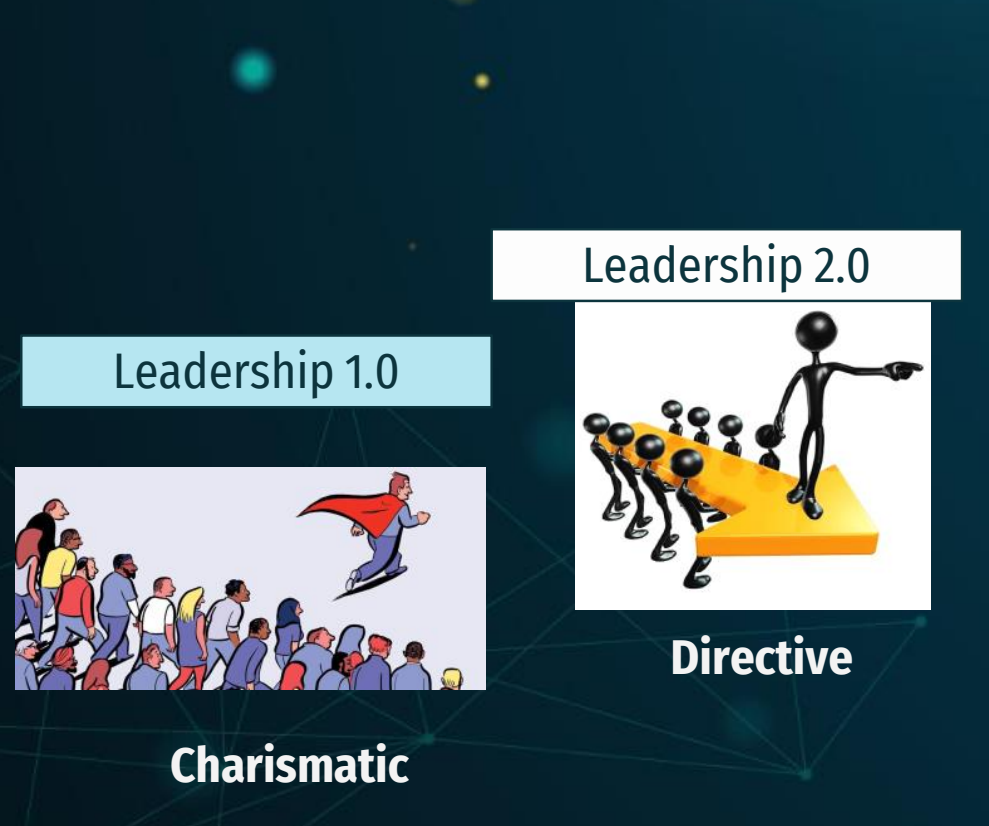

\section{Leadership 3.0}

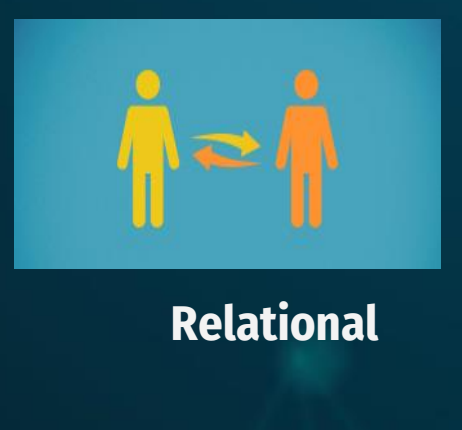

Leadership 4.0

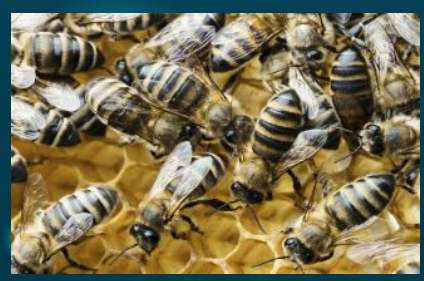

Swarm

- Unity of Mission

- Leader provides the instruments

- No Ego, No Blame

- Generosity of Spirit and Action

- A Foundation of Trust-based Relationships 


\section{Which skills should we have?}

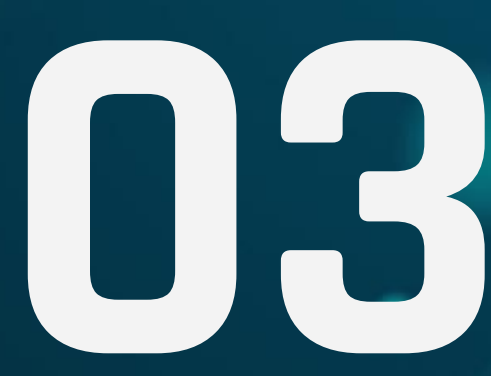




\section{Skills for industry $\mathbf{4 . 0}$}

Technical skills

- No interdisciplinarity, no innovation

- Adaptability to rapid changes and life long learning

- IT skills are the key to survive.

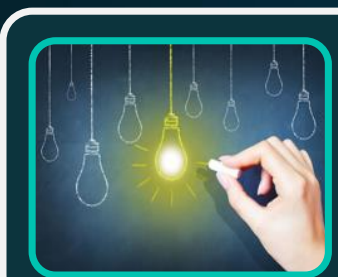

Entrepreneurship

- Collaboration in the „global village “

- Taking risks and dealing with uncertainty

- Responsible creativity

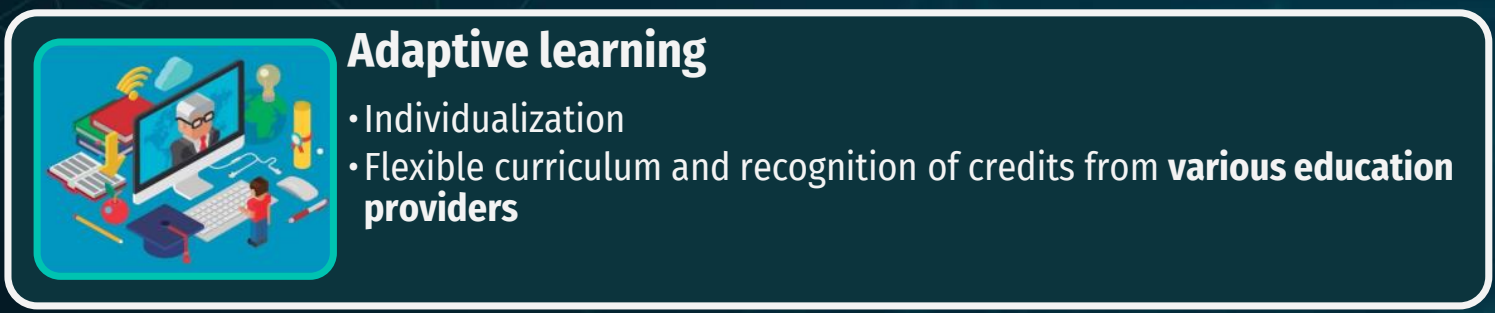




\section{Typology of knowledge workers in industry 4,0}

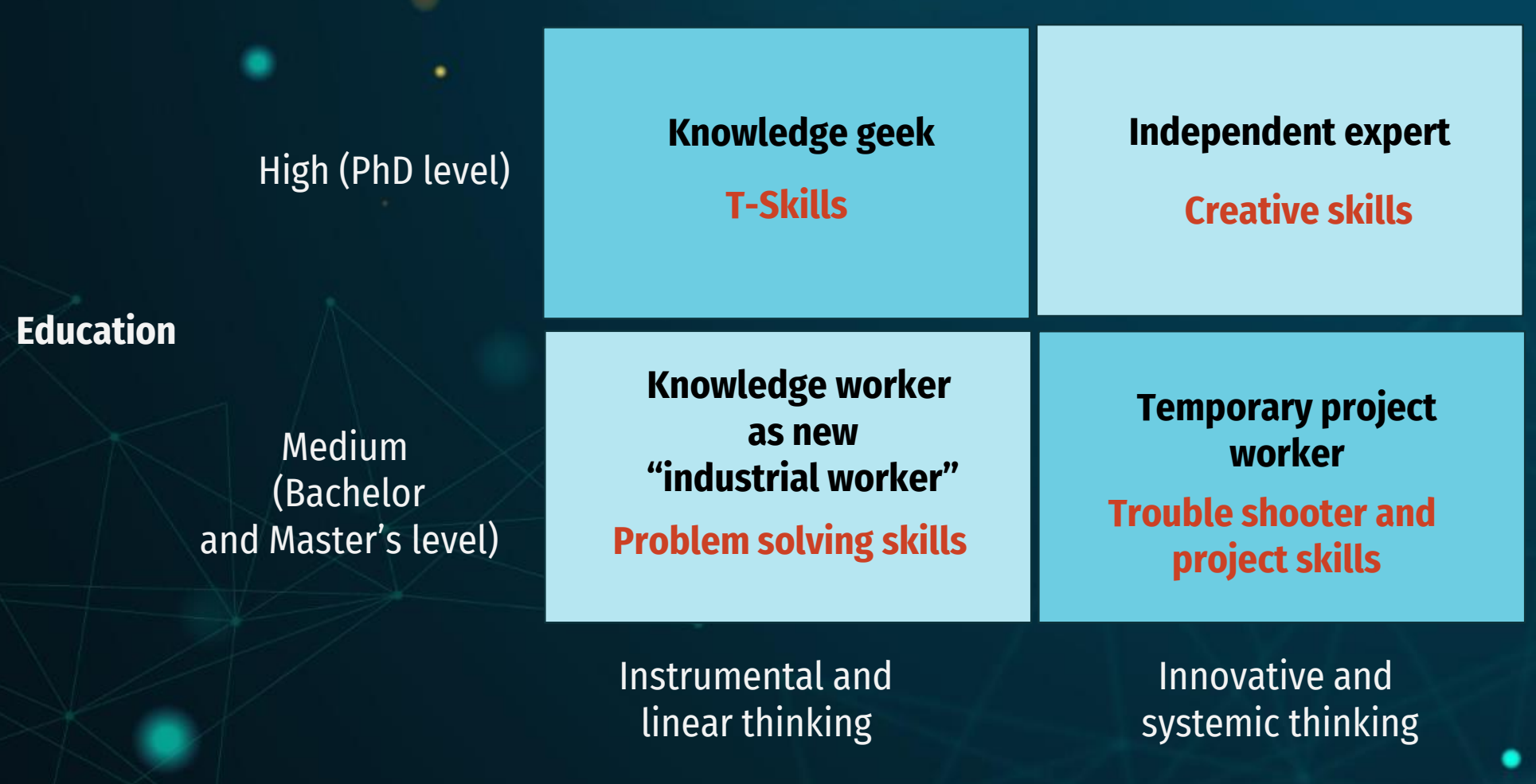


What's next?
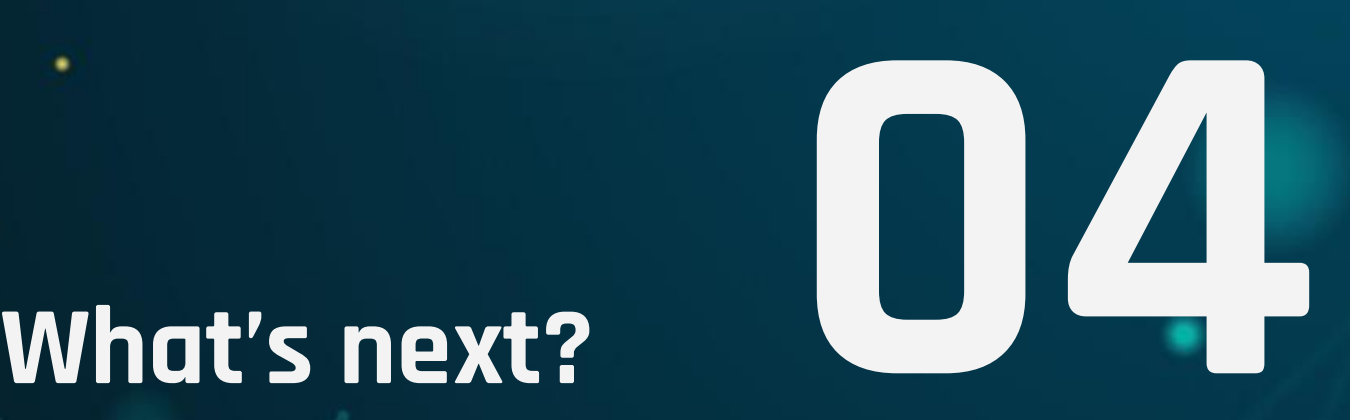


\section{Education (in the broad
sense) is important LESSON 1}


Education is the passport to the future, for tomorrow belongs to those who prepare for it today.

- Malcolm X

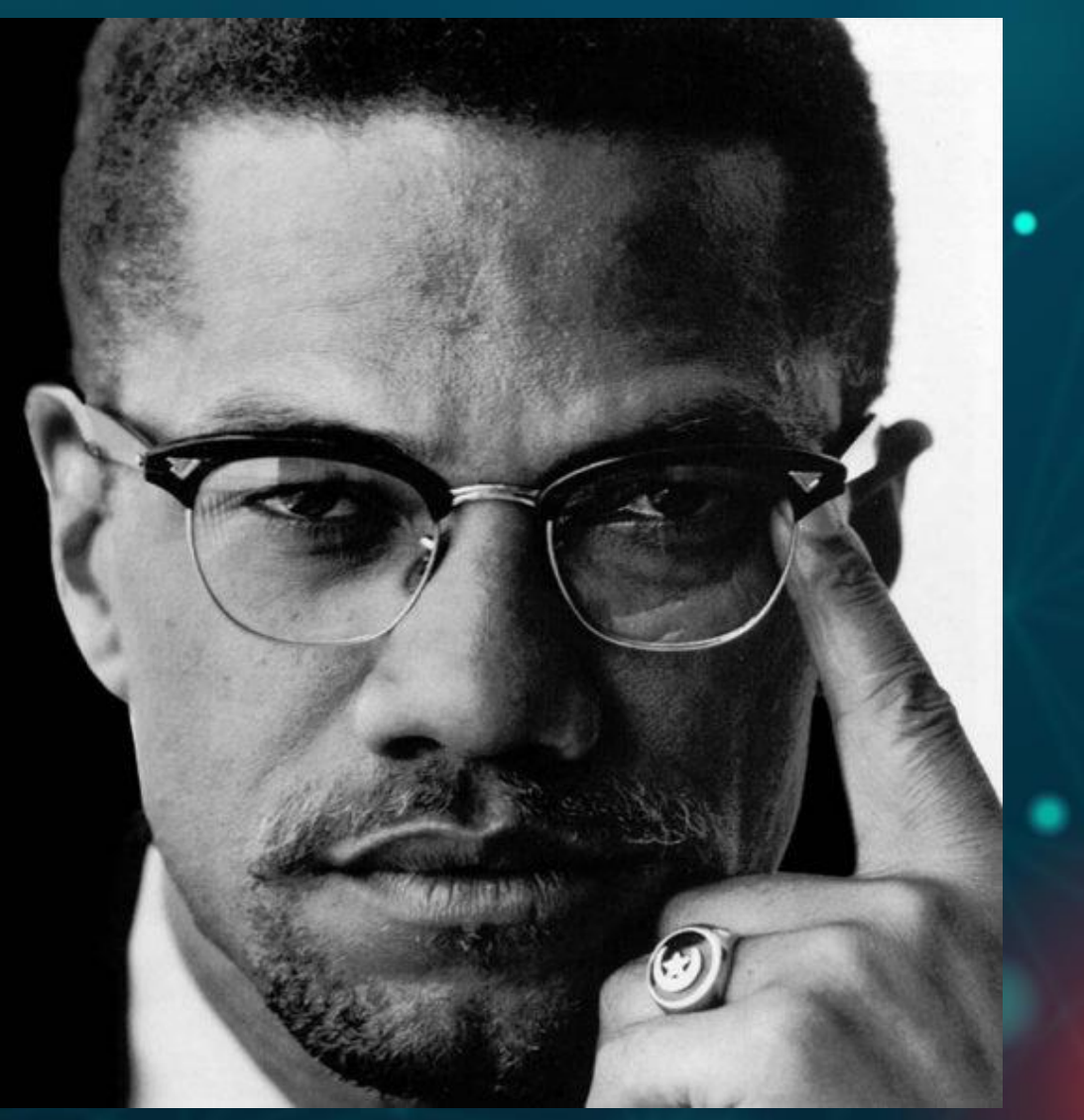



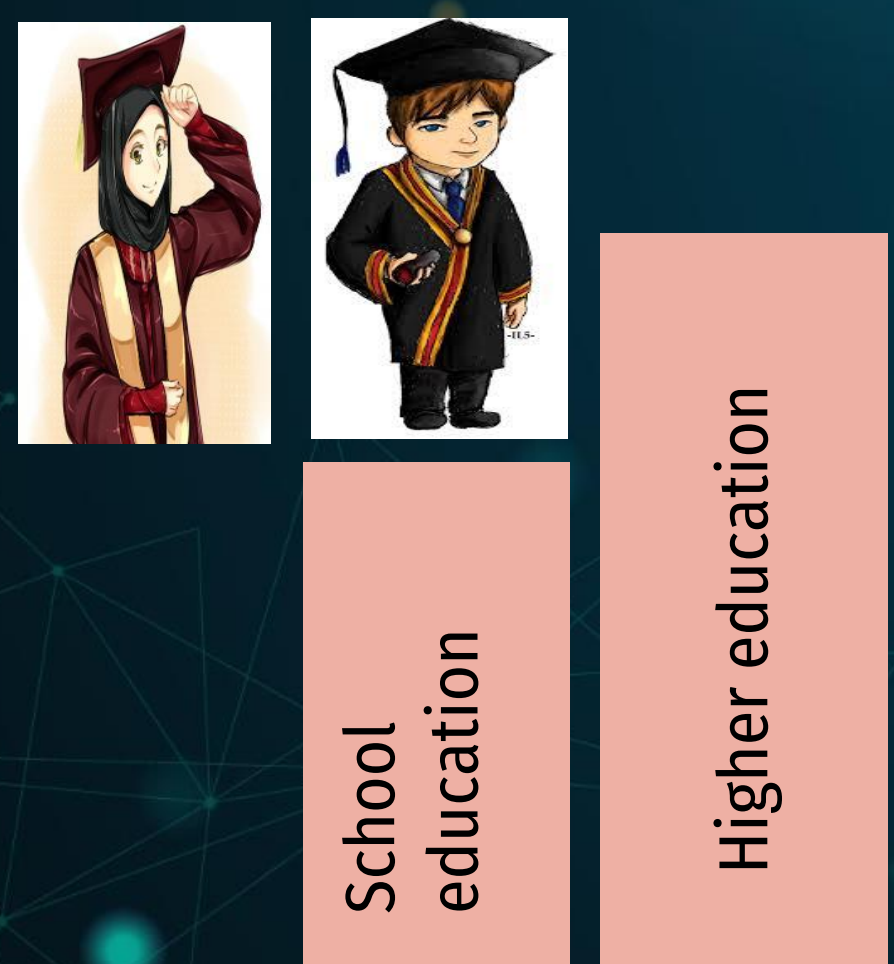

There is no elevator to success,

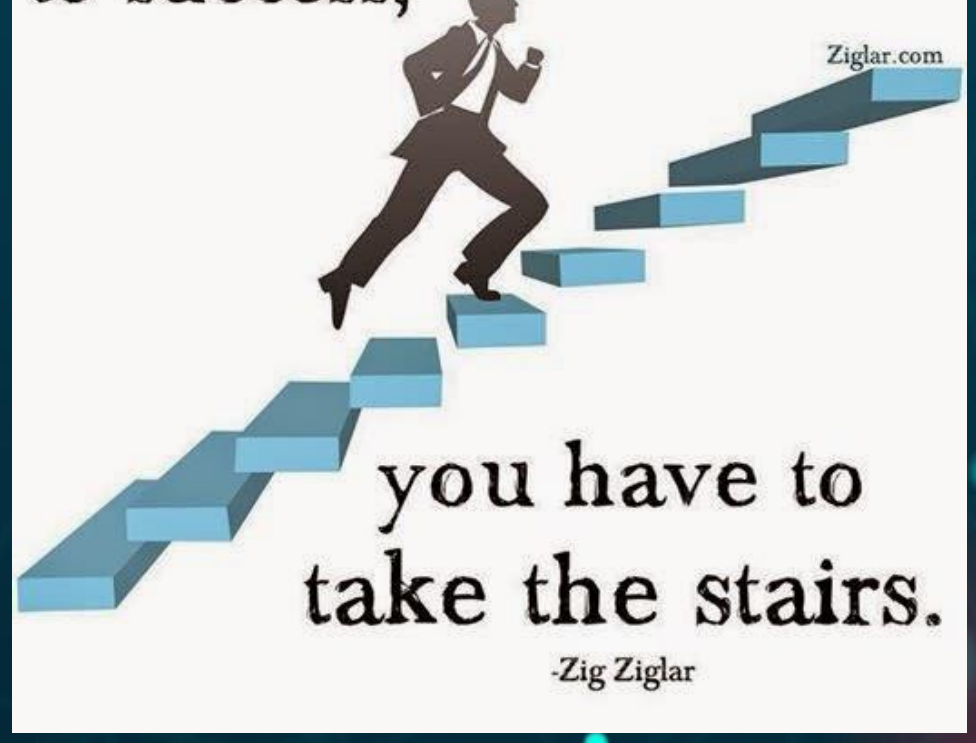


Hard work and trying to
do the best 
"Pendidikan berbekal masa lalu, mendidik masa kini, dan menyiapkan masa depan.

Dalam ruang waktu yang berubah cepat, pembelajar sejati sebagai solusi."

"Masa depan tidak terjadi dengan sendirinya. Kita harus percaya dan bekeria untuk meraihnya."

- Prof. Dr. Muhammad Nuh

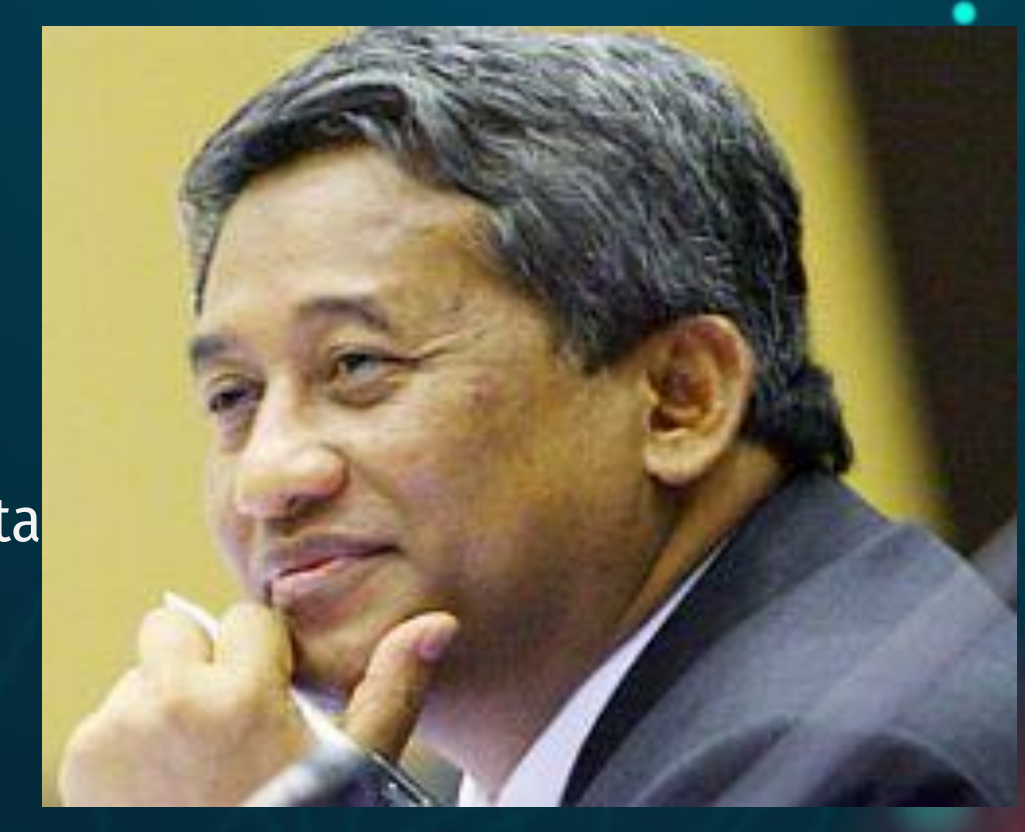


"Kalau besar yang dituntut dan mulia yang dicari,maka payah melaluinya, panjang jalannya dan banyak rintangannya."

- Abu Hamid Al-Ghazali 
“Hendaknya segera mempergunakan masa muda dan umurnya untuk memperoleh ilmu, tanpa terpedaya oleh rayuan "menunda-nunda" dan "berangan-angan panjang", sebab setiap detik yang terlewatkan dari umur tidak akan tergantikan."

- KH Hasyim Asy'ari

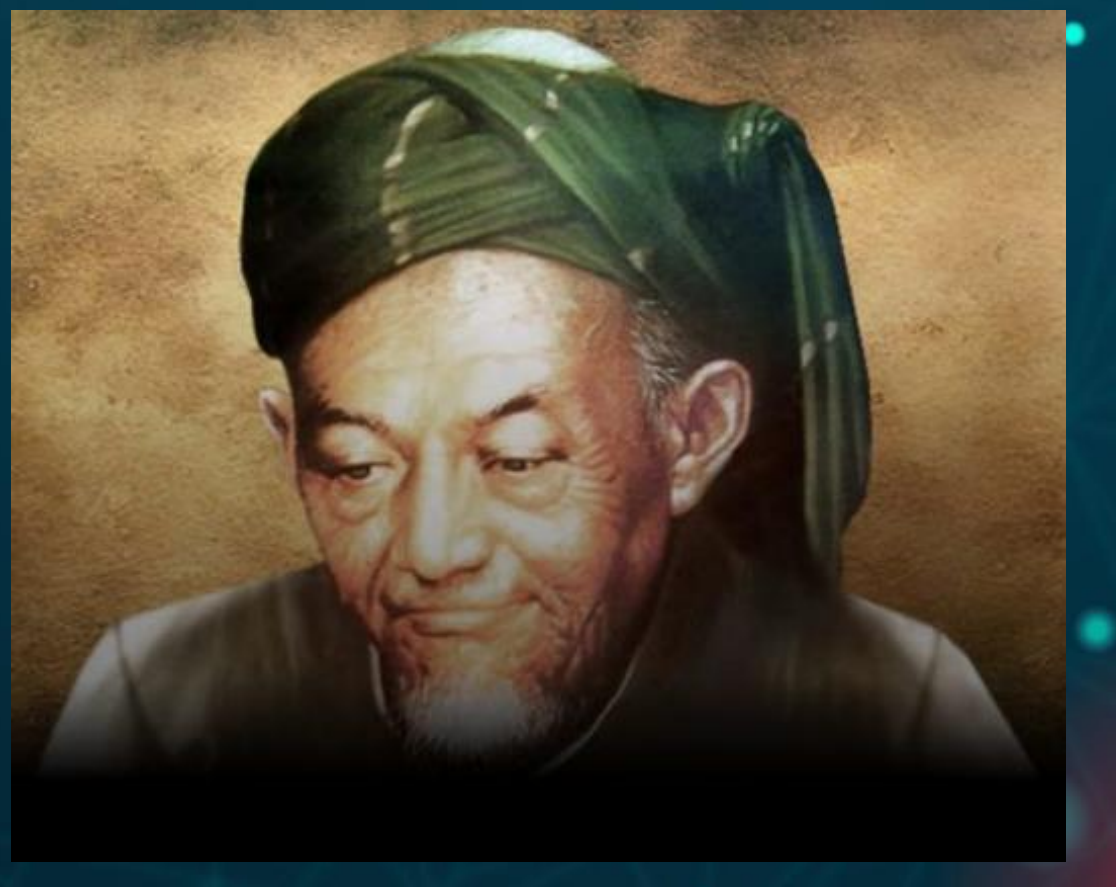




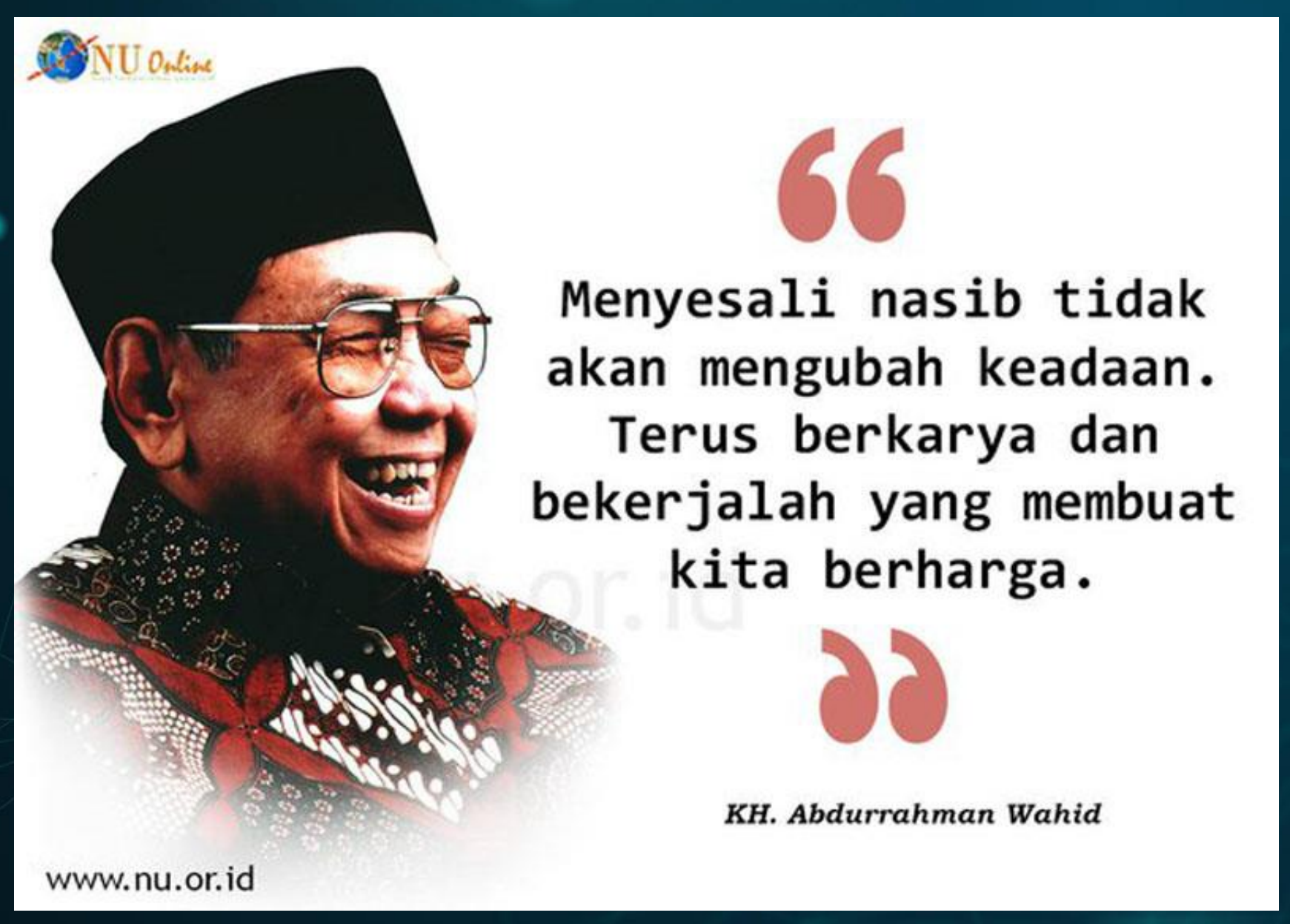




\section{Learn to change, adapt, and become an engine of change




\section{KODAK FILES FOR BANKRUPTCY}

Eastman Kodak Co, a 130-year-old photographic film pioneer, has filed for bankruptcy protection. It said it had also obtained a $\$ 950$ million, 18 -month credit facility from Citigroup to keep it going

SHARE PRICE HISTORY - WEEKLY CLOSE IN US\$

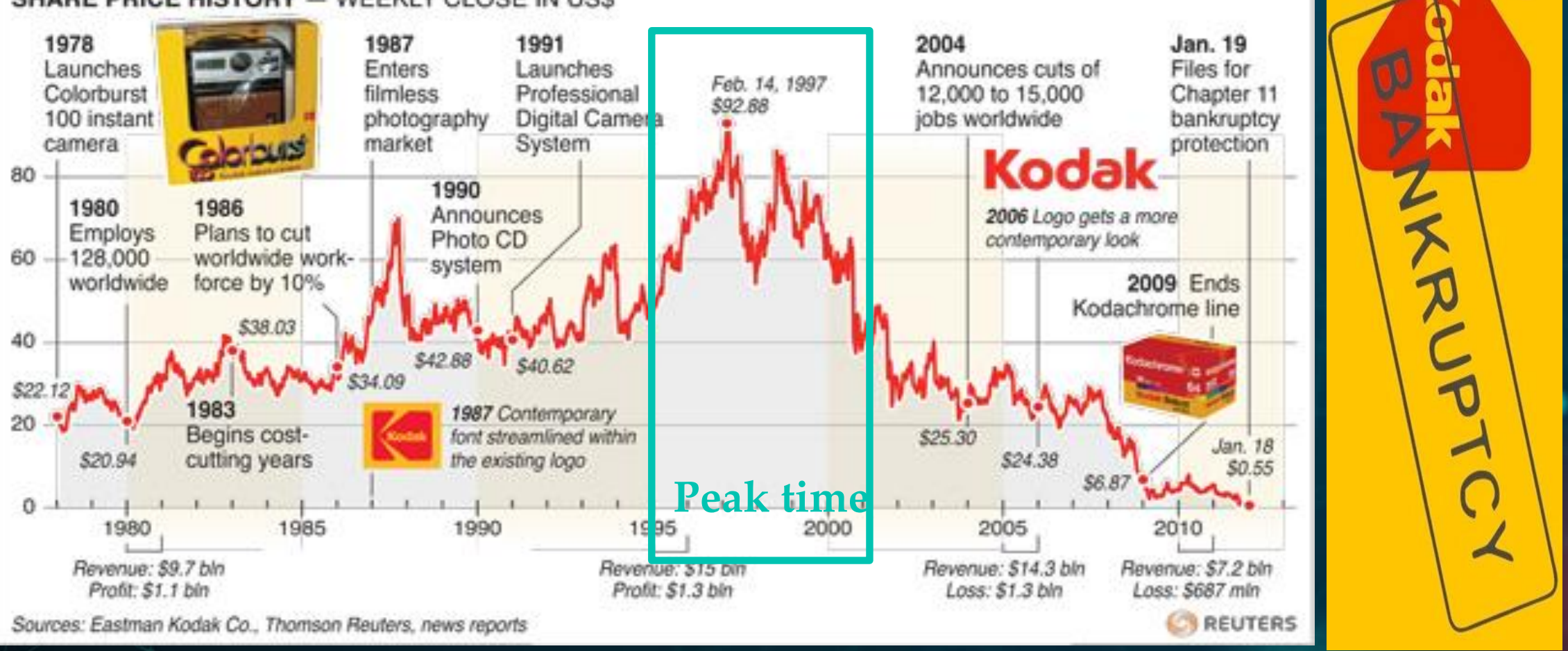




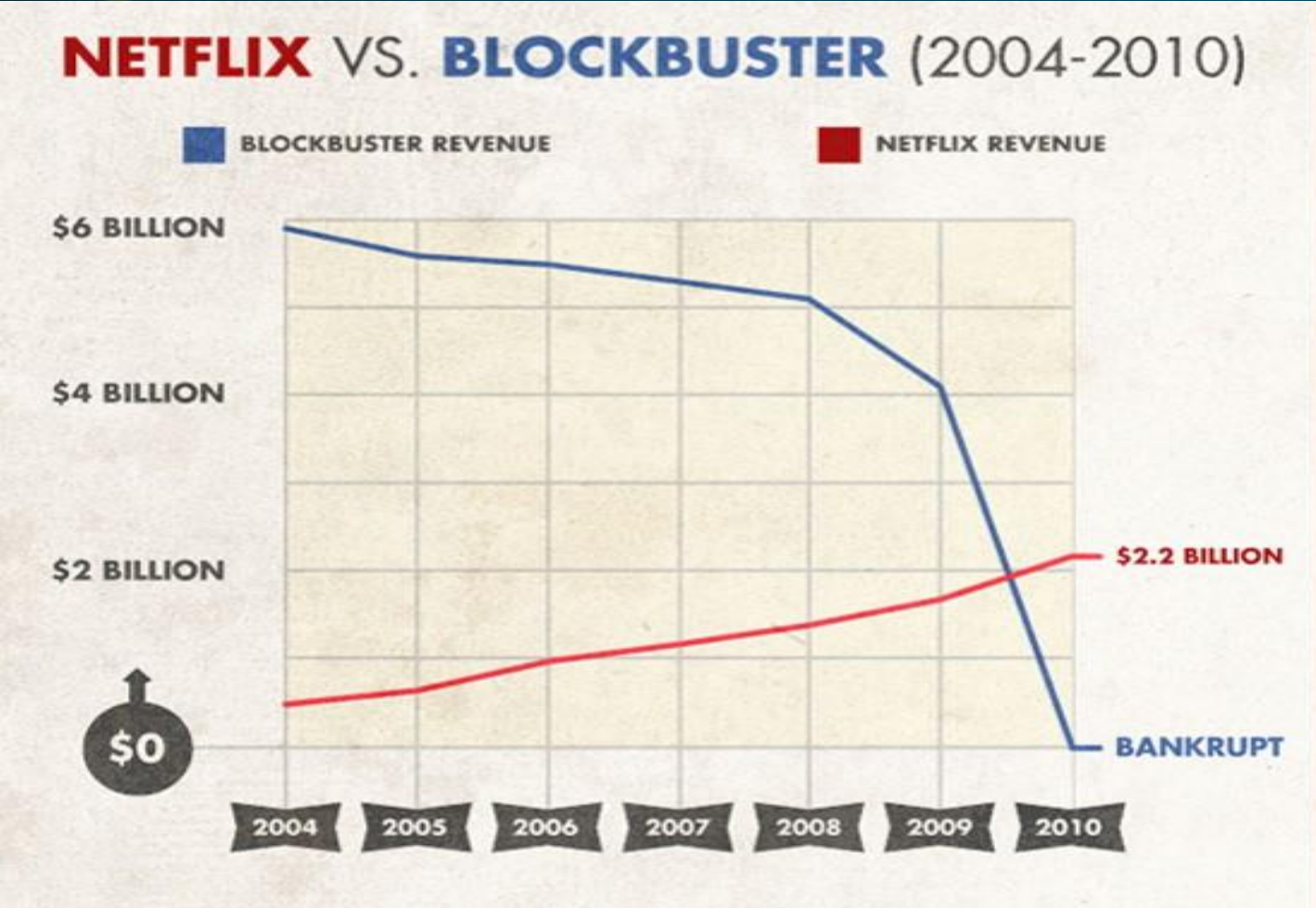




\section{"It is not the strongest of that survives, nor the most intelligent, but the one most responsive to change"}

- Charles Darwin, 1809 


\section{Follower will never be Leader, except____}

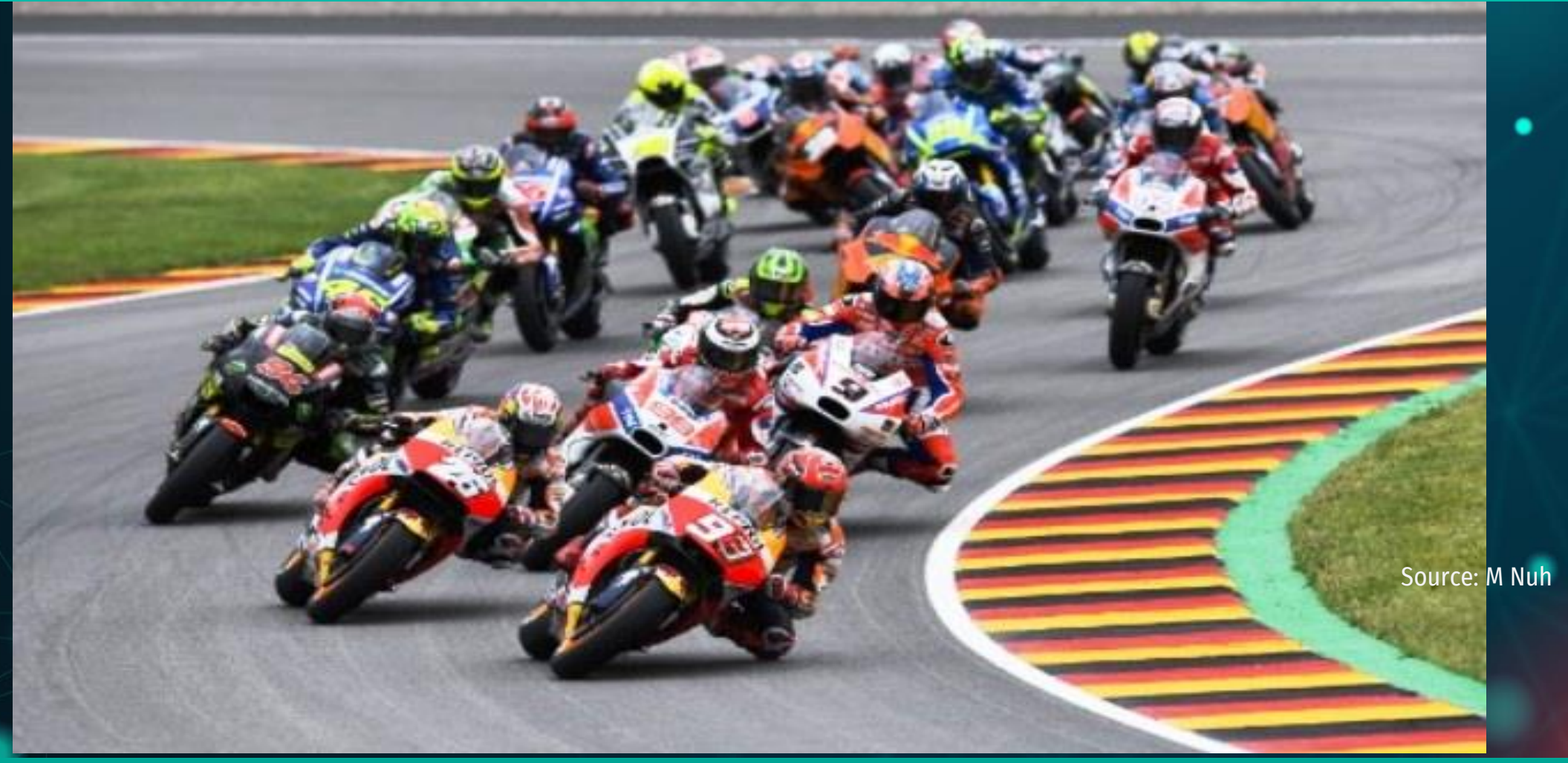

Overtaking almost always happens at the curves: because there are changes 


\section{What should be implemented in indonesia?}

- Wider impacts especially for people living in villages

- Optimizing the value and efficiency of key natural resources of Indonesia.

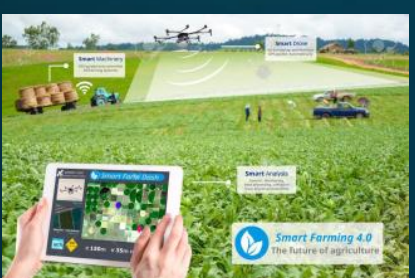

Agriculture 4.0

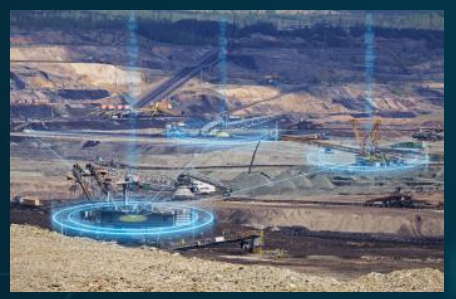

Mining 4.0

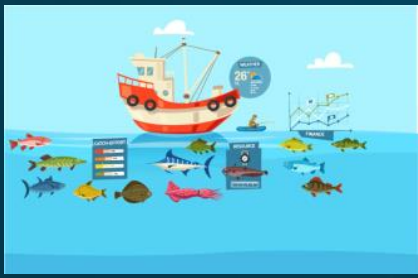

Aquaculture 4.0

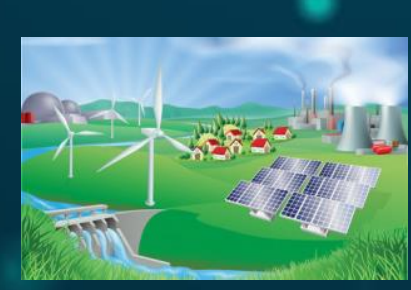

Energy 4.0

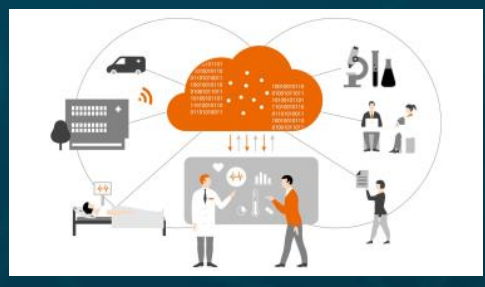

Healthcare 4.0

- Optimizing the roles of all societal elements through ecosystems (villagers + start-ups+ SME+ government + researchers/academia).

- Bringing Indonesia to be leader, not follower. 


\section{Building custom through Habituation}
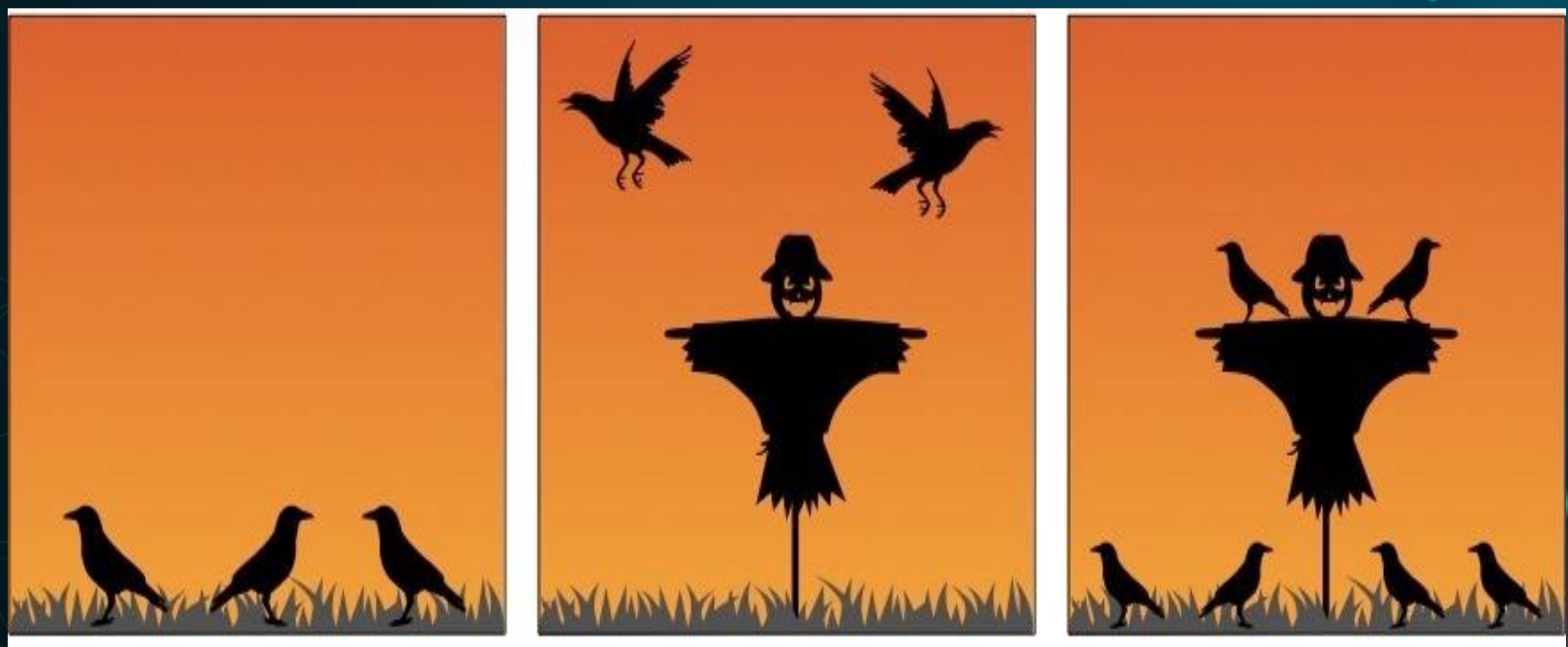


\section{Brain activity response before and after habitugtion}
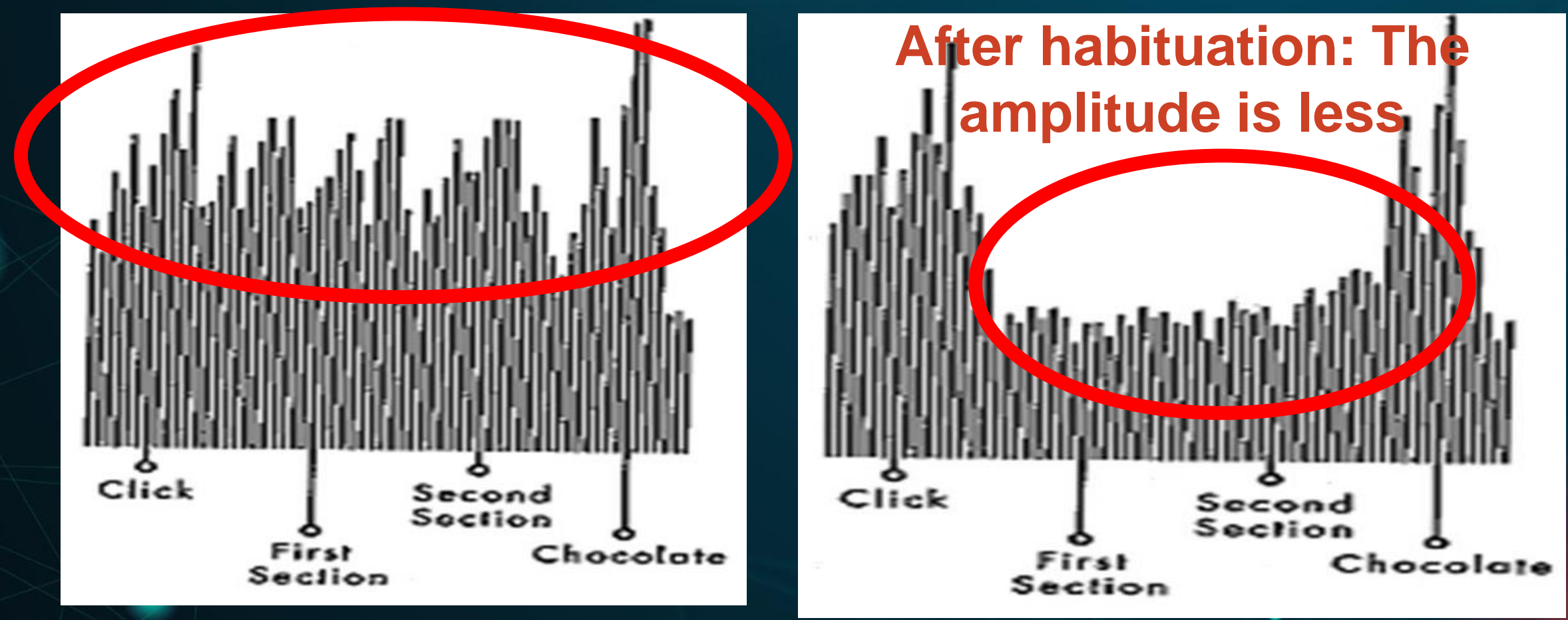


\section{learn to take lessons from natural phenomena and life




\section{QS Ali Imran 190-191}

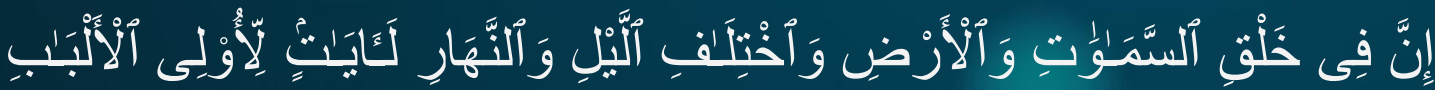

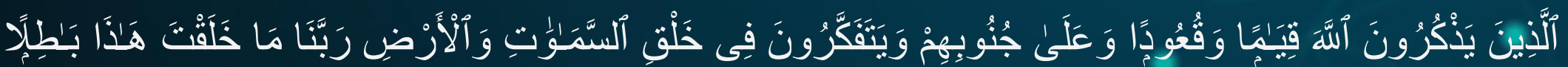

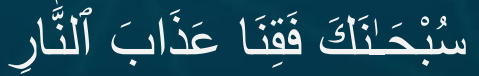

Sesungguhnya dalam penciptaan langit dan bumi, dan pergantian malam dan siang terdapat tandatanda (kebesaran Allah) bagi orang yang berakal. (yaitu) orang-orang yang mengingat Allah sambil berdiri, duduk atau dalam keadaan berbaring, dan mereka memikirkan tentang penciptaan langit dan bumi (seraya berkata), "Ya Tuhan kami, tidaklah Engkau menciptakan semua ini sia-sia; Mahasuci Engkau, lindungilah kami dari azab neraka. 


\section{Learn to be humble and
grateful Lesson 5}


"Orang yang merasa bodoh dan belajar, bisa menjadi pintar. Orang yang merasa pintar, tak akan pernah menjadi pintar."

- KH Mustofa Bisri

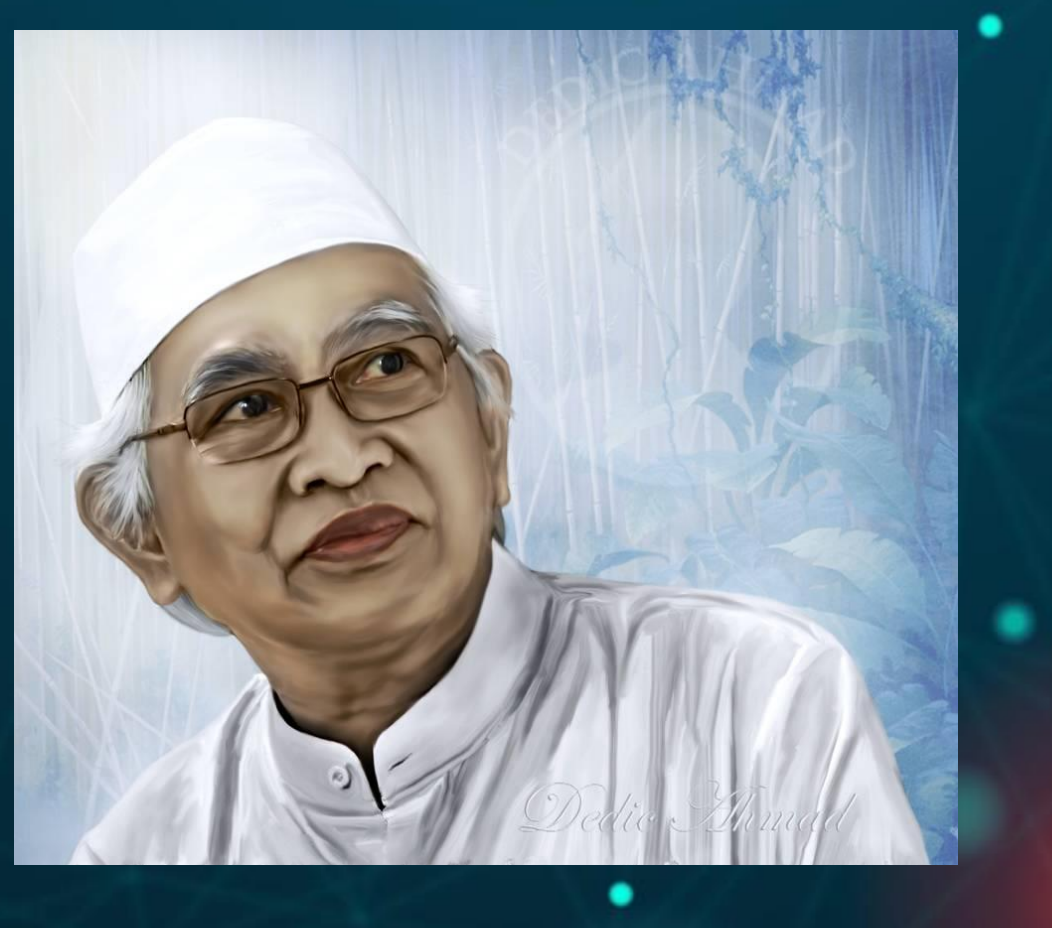


"Semua amal ibadah, baik rohani maupun jasmani, perkataan maupun perbuatan, tidak akan dihitung kecuali disertai perilaku serta budi pekerti yang terpuji. Menghiasi amal di dunia dengan adab (karakter baik) menjadi tanda bahwa amal itu akan diterima kelak di akhirat."

- KH Hasyim Asy'ari

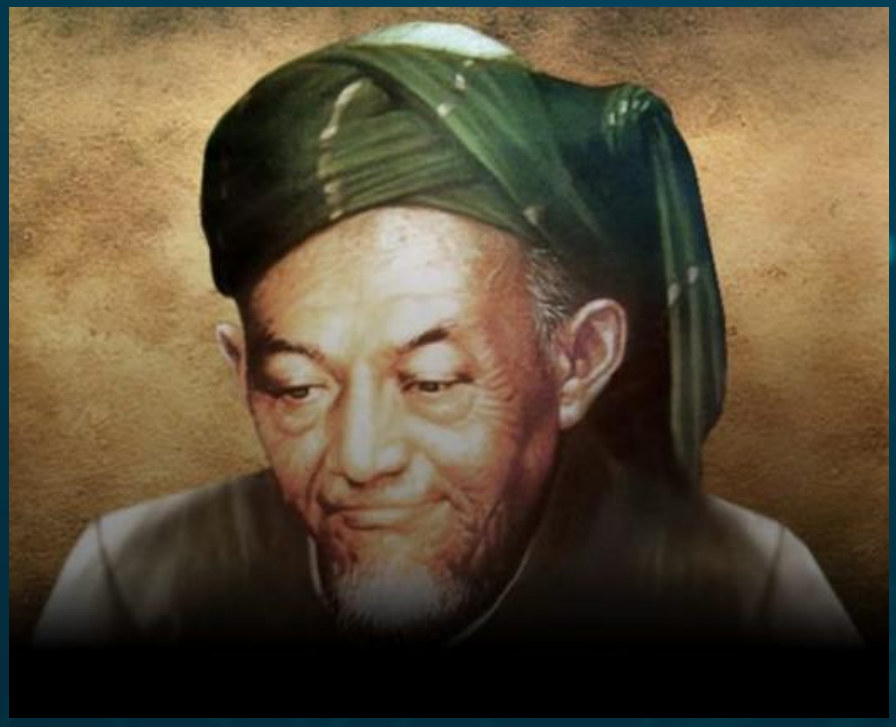




\section{Pentingnya memaknai sanad religiusitas para pahlawan dan mendoakan mereka}

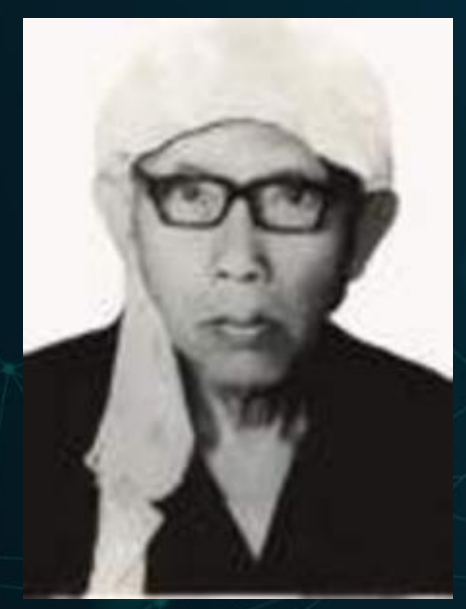

Ayah beliau orang kepercayaan Pangeran Diponegoro KH Hasyim Asy'ari, KH Ahmad Dahlan, dan RA Kartini adalah santri beliau

KH Soleh Darat (1820-1903) 


\section{Berbakti dan berbagi}

Berbakti kepada orang tua dan guru
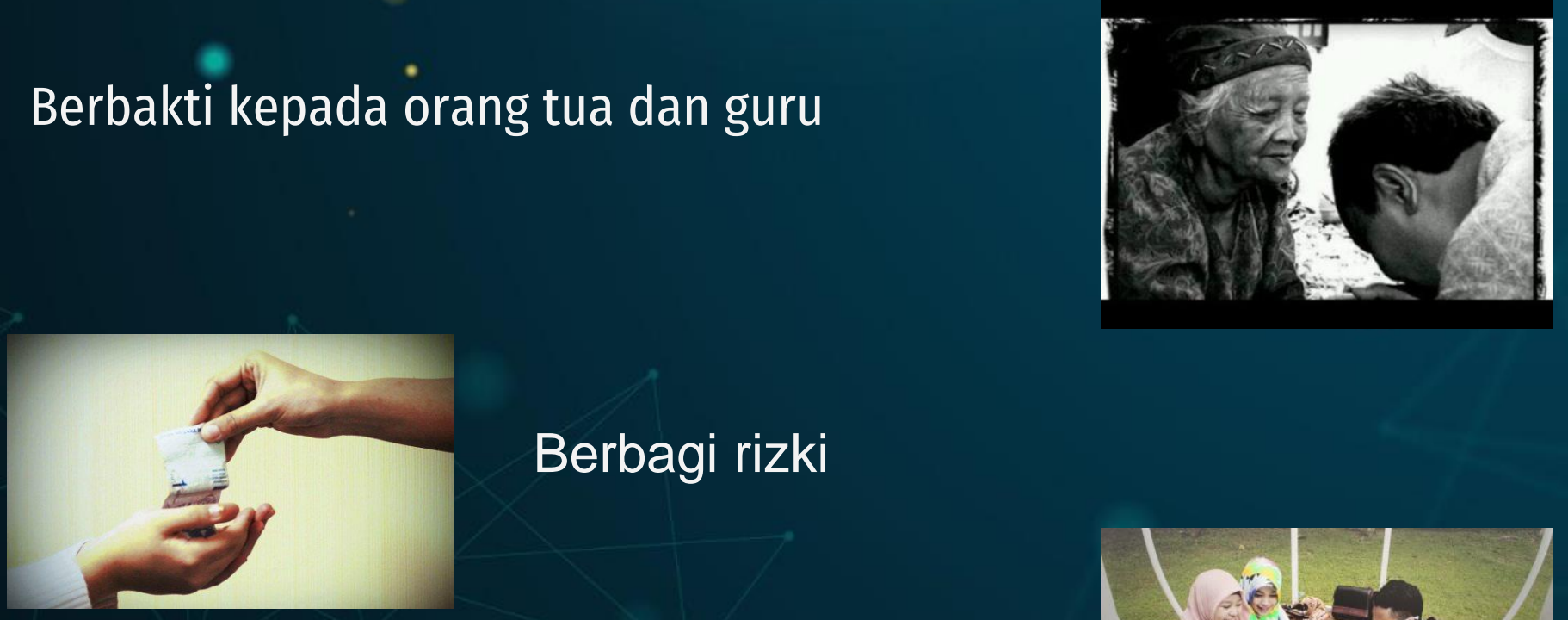

Berbagi rizki

Berbagi ilmu

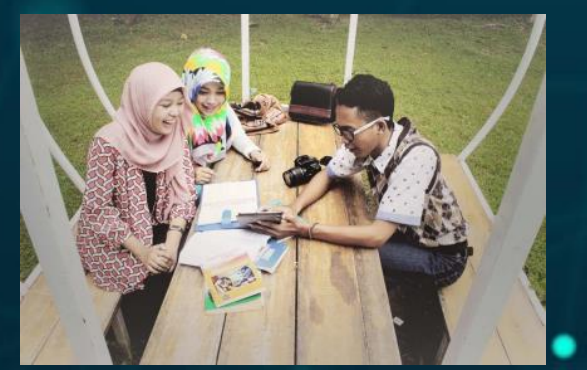




\title{
THANKS:
}

\author{
hendro.wicaksono@green-indonesia.com \\ h.wicaksono@jacobs-university.de \\ +49 17623910735 \\ www.green-indonesia.com
}

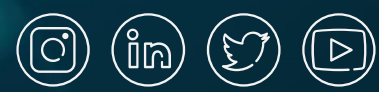

CREDITS: This presentation template was created by Slidesgo, including icons by Flaticon, and infographics \& images by Freepik.

Please keep this slide for attribution. 